Article

\title{
Use of a Zeolite and Molecular Sieve to Restore Homeostasis of Soil Contaminated with Cobalt
}

\author{
Edyta Boros-Lajszner, Jadwiga Wyszkowska *(D) and Jan Kucharski \\ Department of Microbiology, University of Warmia and Mazury in Olsztyn, 10-727 Olsztyn, Poland; \\ edyta.boros@uwm.edu.pl (E.B.-L.); jan.kucharski@uwm.edu.pl (J.K.) \\ * Correspondence: jadwiga.wyszkowska@uwm.edu.pl
}

Received: 18 October 2019; Accepted: 3 January 2020; Published: 6 January 2020

\begin{abstract}
Since contamination of soil with cobalt disturbs the soil's biological balance, various types of compounds are being sought that could be used to restore the homeostasis of contaminated soil. The aim of the study was to determine the use of a Bio.Zeo.S.01 zeolite and molecular sieve in restoring the microbiological and biochemical balance of soil contaminated with cobalt. Soil samples were contaminated with cobalt $\left(\mathrm{CoCl}_{2} \cdot 6 \mathrm{H}_{2} \mathrm{O}\right)$ at $0,20,80 \mathrm{mg} \cdot \mathrm{kg}^{-1}$, and a Bio.Zeo.S.01 zeolite and molecular sieve were introduced at 0 and $15 \mathrm{~g} \cdot \mathrm{kg}^{-1}$. The soils on which the experiment was conducted were loamy sand and sandy clay loam. The experiment was carried out in two series on soil with and without a crop sown in it. The multiplication of microorganisms and the soil enzymes' activity were determined on days 25 and 50 (harvest) of the experiment, and the yield of the underground and above-ground parts of maize and chemical and physical properties of soil were determined on the day of harvest. It was found that the microorganisms' multiplication, enzyme activity, and maize yield were significantly disturbed by the excess of cobalt in the soil regardless of the soil type. The zeolite Bio.Zeo.S.01 used in the study had a smaller impact on microorganisms and soil enzyme activity than the molecular sieve. Cobalt accumulated more in the roots than in the above-ground parts of maize. An addition of sorbents decreased the accumulation of cobalt in maize grown only on sandy clay loam.
\end{abstract}

Keywords: zeolite; molecular sieve; cobalt; microorganisms; soil enzymes; maize

\section{Introduction}

Sorbents are selective towards substances of a certain particle and adsorb smaller particles in dimensions. McBain [1] called these materials molecular sieves, and the effect of this selectivity-the molecular sieve effect. The most numerous and the earliest discovered group of molecular sieves are zeolites, which are characterized by a crystalline and uniform pore structure [2]. These materials have found great application in many areas of chemical technology in the separation and purification of mixtures, in environmental protection, as well as in catalysis. Ion exchange plays an important role in molecular sieves since it enables the use of zeolites in the processes of purification, water softening, and also in the recovery of valuable metals [3]. In addition, they produce efficient active sites accessible to catalytic reagents. Zeolite catalysts also exhibit specific selectivity due to the molecular sieve effect brought about by their high specific surface area, high durability, and regeneration capability [2].

The use of sorbents capable of binding heavy metals prevents the accumulation of these elements, including cobalt, in the soil environment [3]. Trace elements, unlike organic pollutants, are not degraded and depleted but eventually transformed in oxidation states. Originating from a natural source, metals generally do not impair the fertility of the soil and, therefore, do not worsen the conditions for the growth and development of plants [4-6]. However, when soil is contaminated with heavy metals as a result of industrial and economic activities, it poses a serious threat to the homeostasis of the 
environment $[4,5]$. The biological, physical, and chemical properties of the soil deteriorate. Considering the above, modern, environmentally friendly, and effective methods of neutralizing their harmfulness to the environment are being sought. Sometimes, trace elements that pollute the soil are not absorbed by plants; they are bound to other organic or inorganic soil compounds or occur as insoluble sediments. Effective depletion of organic contaminants may be achieved by means of eco-sustainable approaches, such as phytoremediation, bioaugmentation, and biostimulation of microorganisms native to the matrices to be treated [7-10]. In turn, the inorganic contaminant can be extracted from or immobilized in the contaminated matrices by the exploitation of similar eco-sustainable approaches [11-13]. On the other hand, Sun et al. [14] recommended zeolites and other molecular sieves to be exploited to gather inorganic contaminants in contaminated matrices. The homogeneous structure of these sorbents allows for the "trapping" of selected molecules in suitable hollows or ducts, often changing their properties through isolation from external factors [14]. Based on the available literature, the following research hypotheses have been put forward that assume that cobalt chloride may contribute to:

- $\quad$ disturbance of soil homeostasis, through its impact on living organisms living in it and biological processes taking place,

- deterioration of the quality and quantity of yields of plants obtained,

- the accumulation of this heavy metal in soil and above-ground parts and roots of maize,

- $\quad$ eliminating the negative effects of the above-mentioned heavy metal by introducing aluminosilicate minerals of different chemical composition.

For this purpose, the use of sorbents, such as a Bio.Zeo.S.01 zeolite and molecular sieve, was proposed in order to test their usefulness in reducing the negative effect of cobalt on the biological properties of soils and plant yield. In the tests, the content of cobalt in the soil and the plants was also determined, thanks to which it will be possible to assess the degree of the absorption of this metal by the plants. On the basis of the conducted research, an ecological risk assessment could be made by estimating the occurrence of negative ecological effects as a result of the harmful chemical compounds that could be cobalt chloride.

\section{Materials and Methods}

\subsection{Experiment Conditions}

The experiment was conducted in plastic pots, in which $3.5 \mathrm{~kg}$ of soil was placed in the vegetation hall of the University of Warmia and Mazury in Olsztyn (NE parts of Poland 53.7161 ${ }^{\circ} \mathrm{N}, 20.4167^{\circ} \mathrm{E}$ ). Two brown soils were used in the experiment, formed from loamy sand and sandy clay loam, classified as Eutric Cambisols. The soil characteristics are presented in Table 1.

Table 1. Physicochemical properties of the soils used in the experiment.

\begin{tabular}{|c|c|c|c|c|c|c|c|c|c|c|}
\hline \multirow{3}{*}{$\begin{array}{l}\text { Type } \\
\text { of Soil }\end{array}$} & \multicolumn{3}{|c|}{$\begin{array}{l}\text { Granulometric Composition } \\
\text { (mm) }\end{array}$} & \multirow{3}{*}{$\begin{array}{c}\mathrm{C}_{\text {org }} \\
\left(\mathrm{g} \cdot \mathrm{kg}^{-1}\right)\end{array}$} & \multirow{3}{*}{$\mathrm{pH}_{\mathrm{KCl}}$} & \multirow{3}{*}{$\begin{array}{l}\mathrm{N}_{\text {total }} \\
\left(\mathrm{g} \cdot \mathrm{kg}^{-1}\right)\end{array}$} & HAC & EBC & CEC & \multirow{3}{*}{$\begin{array}{l}\text { BS } \\
(\%)\end{array}$} \\
\hline & $<0.002$ & $0.020-0.050$ & $0.050-2.000$ & & & & \multirow{2}{*}{\multicolumn{3}{|c|}{$\left(\mathrm{mmol}^{(+)} \cdot \mathrm{kg}^{-1}\right.$ Soil $)$}} & \\
\hline & & $\%$ & & & & & & & & \\
\hline ls & 1.50 & 18.00 & 80.50 & 6.10 & 7.07 & 0.70 & 7.88 & 85.00 & 92.88 & 91.50 \\
\hline $\mathrm{scl}$ & 2.88 & 27.71 & 69.41 & 14.30 & 7.00 & 0.98 & 6.40 & 165.90 & 172.30 & 96.29 \\
\hline
\end{tabular}

The soil samples were collected in the geologically diverse Olsztyn Lake District, with dominant brown soils-luvisols, stagnic luvisols, and anthropogenic soils. The early post-glacial land relief is typical of the region; it was formed as a result of the North-Poland glaciation (Figure 1). 


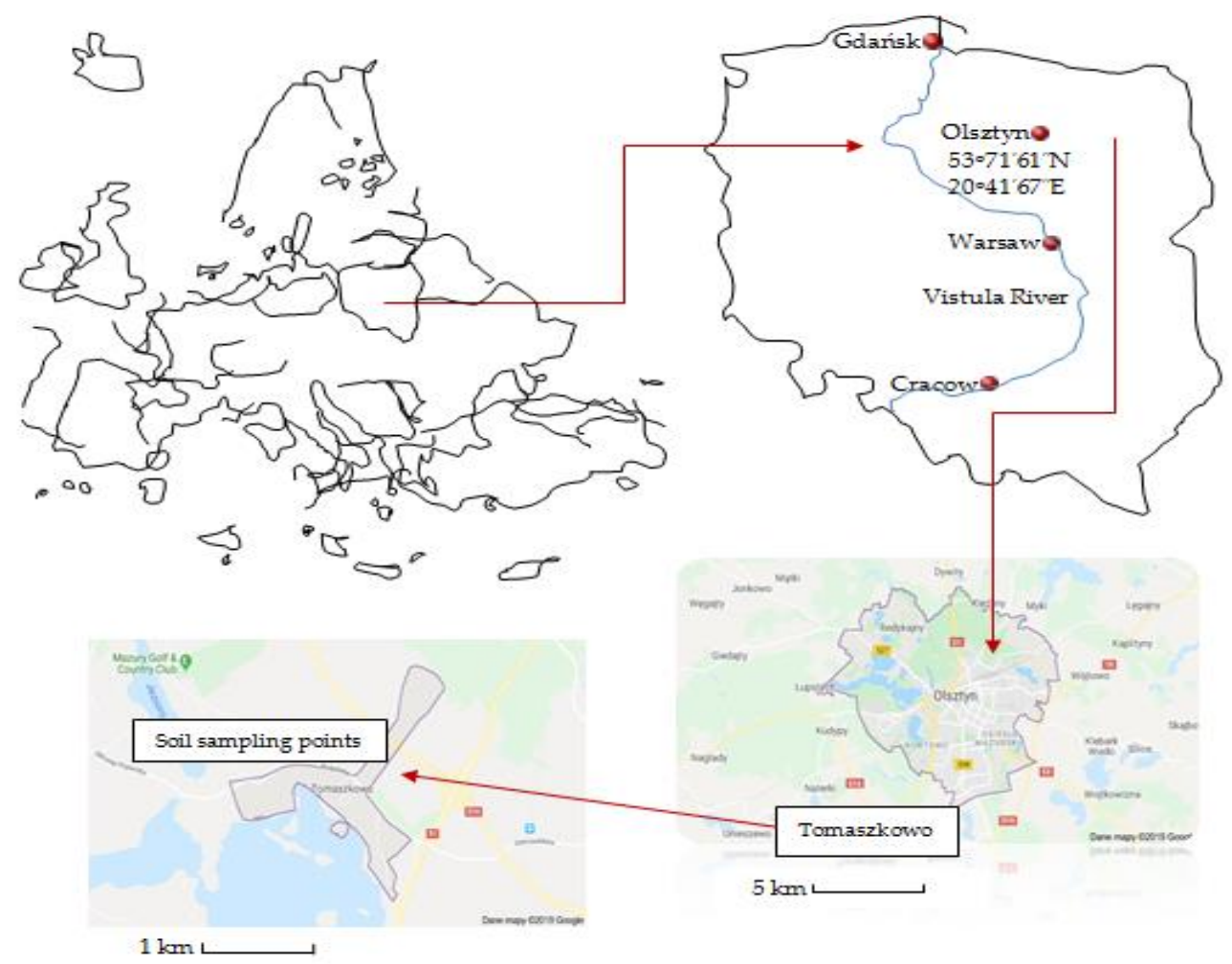

Figure 1. Location of the test site [15].

To begin, 20 and $80 \mathrm{mg} \mathrm{Co}^{2+} \mathrm{kg}^{-1}$ of soil was added to the pots as cobalt chloride $\left(\mathrm{CoCl}_{2} \cdot 6 \mathrm{H}_{2} \mathrm{O}\right)$, together with zeolite and molecular sieve at 0 and $15 \mathrm{~g} \cdot \mathrm{kg}^{-1}$ of soil. The cobalt dose was determined based on the resolution of the Minister of Environment of 1 September 2016, which is in force in Poland [16]. The sorbent dose was selected based on the previously conducted study [17] and the analyzed literature concerning the issues under study $[14,18]$. The sorbent characteristics are presented in Table 2.

Table 2. Characteristics of the sorbents.

\begin{tabular}{|c|c|}
\hline $\begin{array}{c}\text { Molecular Sieve } \\
\text { Company SYLOSIV (Columbia, MD, USA) }\end{array}$ & $\begin{array}{c}\text { Zeolite Bio.Zeo.S.01 } \\
\text { Company BioDrain (Rzeszów, Poland) }\end{array}$ \\
\hline Specification & \\
\hline $\begin{array}{c}\text { Molecular sieve with } 3 \mu \mathrm{m} \text { pores }(\AA \hat{)}) . \\
\text { Total volatile }\left(950^{\circ} \mathrm{C}\right) \% 2.5 \text { max. } \\
\text { GRACE Q } 007 \\
\text { Viscosity of } 50 \mathrm{wt} \% \text { castor oil paste Dynamic } \\
\text { viscosity (Pa.s) } 10-20 \text { GRACE Q } 124 \\
\text { Potlife time } 35 \text { min. GRACE Q } 137 \\
\text { Wet screen residue (>42 } \mu \mathrm{m}) \% 0.01 \text { max. } \\
\text { GRACE Q } 004\end{array}$ & $\begin{array}{l}\text { The composition of Bio.Zeo.S.01 zeolite included the } \\
\text { following elements (\%): } \mathrm{Si}-33.000, \mathrm{Al}-3.2600 \text {, } \\
\text { Fe-0.5176, Ti-0.4255, Mn-0.0126, Ca-2.4442, } \\
\mathrm{Mg}-0.5551, \\
\mathrm{~K}-1.1747, \mathrm{Na}-0.2522 \text {, pure clinoptilolite } \\
\text { content of } 60 .\end{array}$ \\
\hline
\end{tabular}

The soil contaminated with cobalt, but with no sorbents, was used as a control. The soil in the pots was thoroughly mixed with the additives. The experiment was conducted in two variants. The first one included pots sown with maize (Zea mays) of the LG 32.58 cultivar (3 plants per pot); in the second variant, the pots remained unsown. At all objects, permanent fertilization with the following macroelements: $\mathrm{N}-100 \mathrm{mg}\left[\mathrm{CO}\left(\mathrm{NH}_{2}\right)_{2}\right], \mathrm{P}-44 \mathrm{mg}\left[\mathrm{KH}_{2} \mathrm{PO}_{4}\right], \mathrm{K}-100 \mathrm{mg}\left[\mathrm{KH}_{2} \mathrm{PO}_{4}+\mathrm{KCl}\right]$, $\mathrm{Mg}-20 \mathrm{mg}\left[\mathrm{MgSO}_{4} \cdot 7 \mathrm{H}_{2} \mathrm{O}\right]$ was applied. The maize was harvested at the 39 phase $\mathrm{BBCH}$ (Biologische Bundesanstalt, Bundessortenamt and Chemical Scale), and its yield was determined. Soil moisture 
was maintained at $50 \%$ of the capillary water capacity during the entire duration of the experiment. The following were determined twice during the plant growing period; on day 25 at the BBCH 19 phase (9 or more leaves) and day 50 at the BBCH 39 phase:

(a) the soil microorganisms count: Organotrophic bacteria, Actinobacteria, fungi,

(b) the activity of soil enzymes: Dehydrogenases, urease, acid phosphatase, alkaline phosphatase, catalase, arylsulfatase, $\beta$-glucosidase.

The content of cobalt in the above-ground parts and roots, as well as in the soil, was determined after the harvest.

\subsection{Microbiological and Biochemical Analyses of the Soil}

The microbiological and biochemical analyses were conducted by the methods provided in Tables 3 and 4.

Table 3. Medium for determination of counts of soil microorganisms.

\begin{tabular}{|c|c|c|}
\hline Microorganisms & Medium & References \\
\hline Org-organotrophic bacteria & $\begin{array}{c}\text { yeast extract- } 1 \mathrm{~g} \text {; peptone- } 1 \mathrm{~g} ; \\
\mathrm{KH}_{2} \mathrm{PO}_{4}-0.4 \mathrm{~g} ; \mathrm{CaCl}_{2}-0.1 \mathrm{~g} ; \\
\left(\mathrm{NH}_{4}\right)_{2} \mathrm{SO}_{4}-0.5 \mathrm{~g} ; \mathrm{MgSO}_{4} \cdot 7 \mathrm{H}_{2} \mathrm{O}-0.5 \mathrm{~g} ; \\
\text { Mohra salt-0.03 g; agar- } 20 \mathrm{~g} \text {; soil } \\
\text { extract- } 250 \mathrm{~cm}^{3} ; \\
\mathrm{H}_{2} \mathrm{O}-1 \mathrm{dm}^{3} \text {. }\end{array}$ & Alexander [19] \\
\hline Act-actinomycetes & $\begin{array}{c}\text { soluble starch-10 g; casein-0.3 g; } \\
\mathrm{KNO}_{3}-2 \mathrm{~g} ; \mathrm{NaCl}-2 \mathrm{~g} ; \mathrm{K}_{2} \mathrm{HPO}_{4}-2 \mathrm{~g} ; \\
\mathrm{MgSO}_{4} \cdot 7 \mathrm{H}_{2} \mathrm{O}-0.05 \mathrm{~g} ; \mathrm{CaCO}_{3}-0.02 \mathrm{~g} ; \\
\mathrm{FeSO}_{4}-0.01 \mathrm{~g} ; \text { agar }-20 \mathrm{~g} ; \mathrm{H}_{2} \mathrm{O}-1 \mathrm{dm}^{3} ; \\
50 \mathrm{~cm}^{3} \text { aqueous solution of nystatin } 0.05 \% \\
50 \mathrm{~cm}^{3} \text { aqueous solution of actidione } 0.05 \% \\
\mathrm{pH}-7 \text {; }\end{array}$ & Parkinson et al. [20] \\
\hline Fun-fungi & $\begin{array}{c}\text { Peptone }-5 \mathrm{~g} ; \mathrm{K}_{2} \mathrm{HPO}_{4}-1 \mathrm{~g} \text {; glucose }-10 \mathrm{~g} ; \\
\mathrm{MgSO}_{4} \cdot 7 \mathrm{H}_{2} \mathrm{O}-0.5 \mathrm{~g} ; \text { agar }-20 \mathrm{~g} ; \\
\mathrm{H}_{2} \mathrm{O}-1 \mathrm{dm}^{3} ; 3.3 \mathrm{~cm}^{3} \text { aqueous solution of } \\
\text { bengal rose } 1 \% ; \\
25 \mathrm{~cm}^{3} \text { aqueous solution of aureomycin } \\
0.01 \% ; \mathrm{pH}-5.9 .\end{array}$ & Martin [21] \\
\hline
\end{tabular}

Determinations of enzymatic activity of the soil, except catalase, were conducted using a Perkin-Elmer Lambda 25 spectrophotometer (Waltham, MA, USA). The following wavelengths were used: For dehydrogenases, $\lambda=485 \mathrm{~nm}$; for urease, acid phosphatase, and alkaline phosphatase, $\lambda$ $=410 \mathrm{~nm}$; for $\beta$-glucosidase, $\lambda=400 \mathrm{~nm}$; for arylsulfatase, $\lambda=420 \mathrm{~nm}$. The bioconcentration index $\left[I B_{C o}\right]$ was calculated from the cobalt content in the above-ground parts of maize and roots. Moreover, the element uptake by the plant and its distribution in the above-ground parts and the roots was calculated from the formulas provided in Boros-Lajszner et al. [17] and Kaczynska et al. [24]:

$$
I F_{C o}=\frac{A_{C o}}{A_{0}}
$$

where $I F_{C_{o}}$ is an index of cobalt impact, $A_{C_{o}}$ is counts of microorganisms/activity of enzymes in soil contaminated with cobalt, $A_{0}$ is counts of microorganisms/activity of enzymes in uncontaminated soil.

$$
I F_{s / z}=\frac{A_{s / z}}{A}
$$


where $I F_{s / z}$ is an index of molecular sieve/zeolite impact, $A_{s / z}$ is counts of microorganisms/activity of enzymes in soil with an addition of molecular sieve/zeolite, $A$ is counts of microorganisms/activity of enzymes soil without addition of molecular sieve/zeolite.

$$
I B_{C o}=\frac{C_{A}}{C_{S}}
$$

where $I B_{C o}$ is bioconcentration index, $C_{A}$ is cobalt content in above-ground parts, $C_{S}$ is cobalt content in the soil.

Table 4. Methods of determination of soil enzyme activity.

\begin{tabular}{|c|c|c|c|}
\hline Enzyme & Substrate & Product/Unit & References \\
\hline $\begin{array}{l}\text { Deh—dehydrogenases } \\
\text { (EC 1.1) }\end{array}$ & $\begin{array}{l}\text { 2,3,5-Triphenyl } \\
\text { tetrazolium chloride } \\
\text { (TTC) }\end{array}$ & $\begin{array}{l}\text { triphenylfomazan (TFF), } \\
\mu \mathrm{mol} \cdot \mathrm{kg}^{-1} \text { d.m. of soil } \mathrm{h}^{-1}\end{array}$ & Öhlinger [22] \\
\hline $\begin{array}{l}\text { Cat-catalase } \\
(\text { EC 1.11.1.6) }\end{array}$ & $\mathrm{H}_{2} \mathrm{O}_{2}$-aqueous solution & $\mathrm{O}_{2}, \mathrm{~mol} \cdot \mathrm{kg}^{-1} \mathrm{~d} . \mathrm{m}$. of soil $\mathrm{h}^{-1}$ & \multirow{6}{*}{$\begin{array}{c}\text { Alef and } \\
\text { Nannpieri [23] }\end{array}$} \\
\hline Ure-urease (EC 3.5.1.5) & urea-aqueous solution & $\begin{array}{l}\mathrm{N}-\mathrm{NH}_{4}, \mathrm{mmol} \cdot \mathrm{kg}^{-1} \mathrm{~d} . \mathrm{m} . \\
\text { of soil h}{ }^{-1}\end{array}$ & \\
\hline $\begin{array}{l}\text { Glu- } \beta \text {-glucosidase } \\
\quad(\text { EC 3.2.1.21) }\end{array}$ & $\begin{array}{l}\text { 4-nitrophenyl- } \beta- \\
\text { D-glucopyranoside } \\
\text { (PNG) }\end{array}$ & $\begin{array}{l}\text { 4-nitrophenol (PN), } \\
\mathrm{mmol} \cdot \mathrm{kg}^{-1} \text { d.m. of soil } \mathrm{h}^{-1}\end{array}$ & \\
\hline $\begin{array}{c}\text { Pac- acid phosphatase } \\
\text { (EC 3.1.3.2) }\end{array}$ & $\begin{array}{l}\text { Disodium 4-nitrophenyl } \\
\text { phosphate hexahydrate } \\
\text { (PNP) }\end{array}$ & $\begin{array}{l}\text { 4-nitrophenol (PN), } \\
\mathrm{mmol} \cdot \mathrm{kg}^{-1} \text { d.m. of soil } \mathrm{h}^{-1}\end{array}$ & \\
\hline $\begin{array}{c}\text { Pal-alkaline } \\
\text { phosphatase (EC 3.1.3.1) }\end{array}$ & $\begin{array}{c}\text { Disodium 4-nitrophenyl } \\
\text { phosphate hexahydrate } \\
\text { (PNP) }\end{array}$ & $\begin{array}{l}\text { 4-nitrophenol (PN), } \\
\text { mmol } \cdot \mathrm{kg}^{-1} \text { d.m. of soil } \mathrm{h}^{-1}\end{array}$ & \\
\hline $\begin{array}{l}\text { Aryl—arylsulfatase } \\
\text { (EC 3.1.6.1) }\end{array}$ & $\begin{array}{c}\text { Potassium-4- } \\
\text { nitrophenylsulfate (PNS) }\end{array}$ & $\begin{array}{l}\text { 4-nitrophenol (PN), } \\
\mathrm{mmol} \cdot \mathrm{kg}^{-1} \text { d.m. of soil } \mathrm{h}^{-1}\end{array}$ & \\
\hline
\end{tabular}

\subsection{Physical and Chemical Analyses of the Soil}

The following physical and chemical properties of the soil were determined:

$\checkmark \quad \mathrm{pH}$ of the soil, total exchangeable base cations (EBC), hydrolytic acidity (HAC), total organic carbon $\left(\mathrm{C}_{\text {org }}\right)$, and total nitrogen $\left(\mathrm{N}_{\text {Total }}\right)$, as well as soil saturation with basic cations (BS) and the total cation exchange capacity of the soil (CEC). The determination procedure was provided in Boros-Lajszner et al. [17].

$\checkmark \quad$ the cobalt content in the soil, determined by the flame atomic absorption spectrometry on an ICE (International Electrotechnical Commission) atomic absorption spectrometer (Thermo Scientific; Waltham, MA, USA) as per PN-ISO 11047 [25].

$\checkmark \quad$ cobalt content in the above-ground parts and roots, determined by flame atomic absorption spectrometry and by graphite furnace atomic absorption spectroscopy (FAAS and GFAAS) following microwave mineralization.

\subsection{Statistical Analyses}

By means of the Statistica 13.1 (StatSoft, Tulsa, OK, USA), the results were analyzed statistically with the ANOVA analysis [26]. Pearson's simple correlation coefficients between cobalt dose and microbial count, enzyme activity, plant yield, cobalt content, and the physicochemical properties of soil were calculated. Principal component analysis (PCA) was used to analyze the number and 
activity of enzymes in the soil contaminated with cobalt and with an addition of sorbents. The coefficient of percentage variability of all analyzed variables $(\eta 2)$ was determined by the analysis of variance-ANOVA.

\section{Results}

\subsection{Microorganisms Count}

In the experiment, cobalt affected the count of organotrophic bacteria, Actinobacteria, and fungi. The number of microorganisms depended mainly on the dose of cobalt (the percentage of variability ranged from 15 to 21), the type of sorbent (the percentage of variability ranged from 5 to 16), the type of soil (the percentage of variability ranged from 1 to 38), the manner of use (the percentage of variability ranged from 12 to 39), and the date of analysis (variability ranged from $8 \%$ to $24 \%$ ). Table 5 presents the count in the non-contaminated soil. The obtained results indicated a higher microbial count in the soil sown with maize, compared to the unsown soil in both soils. The organotrophic bacterial and fungal count was higher in the loamy sand in objects sown with a crop. However, the actinobacterial count was higher in the sandy-clay soil.

Table 5. The counts of microorganisms in non-contaminated soil.

\begin{tabular}{|c|c|c|c|}
\hline Soil Use & $\begin{array}{c}\text { Org } \\
\text { (cfu } 10^{8} \mathrm{~kg}^{-1} \text { d.m.) }\end{array}$ & $\begin{array}{c}\text { Act } \\
\text { (cfu } 10^{8} \mathrm{~kg}^{-1} \text { d.m.) }\end{array}$ & $\begin{array}{c}\text { Fun } \\
\left(\mathrm{cfu} 10^{6} \mathrm{~kg}^{-1} \text { d.m.) }\right.\end{array}$ \\
\hline \multicolumn{4}{|c|}{ Loamy sand } \\
\hline Sown soil & 194.420 & 142.240 & 201.580 \\
\hline Unsown soil & 95.170 & 108.210 & 132.200 \\
\hline \multicolumn{4}{|c|}{ Sandy clay loam } \\
\hline Sown soil & 121.450 & 186.590 & 96.040 \\
\hline Unsown soil & 101.220 & 101.740 & 41.840 \\
\hline
\end{tabular}

Org—organotrophic bacteria; Act—Actinobacteria; Fun—fungi; cfu—colony-forming unit.

The principal component analysis (PCA) of the microorganism count demonstrated the inhibitory effect of cobalt on the tested parameters (Figure 2a,b). The position of vectors indicatedthe similarity of the reaction of two groups of microorganisms: In loamy sand (Figure 2a)—of fungi and Actinobacteria, and in sandy clay loam (Figure $2 b$ ) —of organotrophic bacteria and fungi. The occurrence of these microorganisms was limited by the smallest dose $\left(20 \mathrm{mg} \mathrm{Co}^{2+} \mathrm{kg}^{-1}\right.$ of soil $)$ and increased with increased cobalt contamination ( $80 \mathrm{mg} \mathrm{Co}{ }^{2+} \mathrm{kg}^{-1}$ of soil). The distribution of cases with respect to the vectors describing these groups of microorganisms indicated the stimulating action of the Bio.Zeo.S.01 zeolite and the molecular sieve. The highest number of microorganisms was observed on the 60th day of the experiment, which was confirmed by the distribution of cases in relation to the vectors.

Contamination of the soil with cobalt contributed to changes in the microbiological properties of the soil. This was reflected in the index $\left(I F_{C_{0}}\right)$ of the effect of the metal under the study on the microorganism count (Table 6). The negative effect of cobalt on the microbiome increased with the increase in the amount of this element in the substrate regardless of the soil type. This was particularly evident for organotrophic bacteria and Actinobacteria in the soil without a crop sown on it and fungi in the soil with a crop sown on it. 


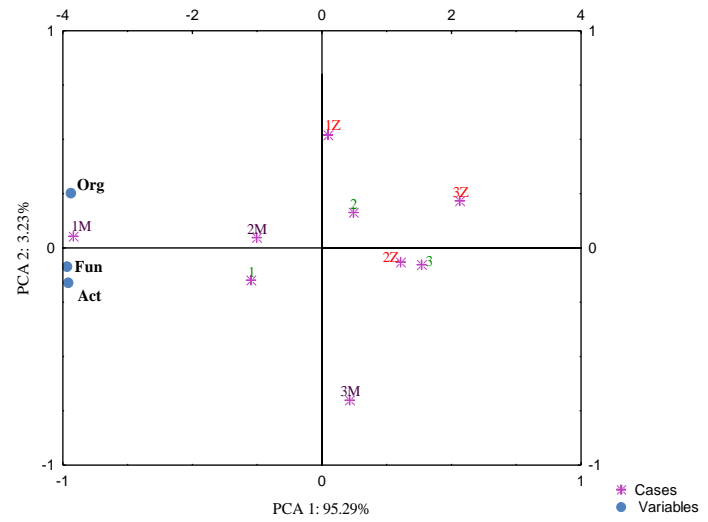

(a)

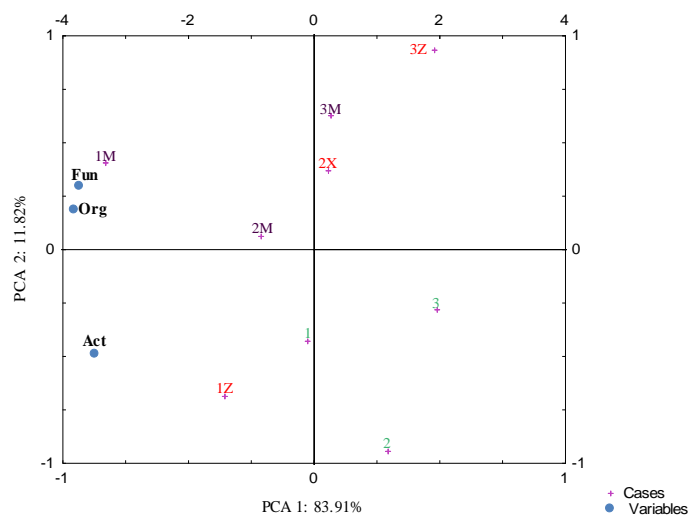

(b)

Figure 2. Count of selected groups of microorganisms in soil contaminated with cobalt: (a) loamy sand; (b) sandy clay loam; Org-organotrophic bacteria; Act-Actinobacteria; Fun-fungi; dose $\mathrm{Co}^{2+} \mathrm{mg}^{2} \mathrm{~kg}^{-1}$ d.m. of soil: $1-0 ; 2-20 ; 3-80$; Z—zeolite Bio.Zeo.S.01; M-molecular sieve.

Table 6. Index of cobalt effect $\left(I F_{C o}\right)$ on the microorganism count.

\begin{tabular}{|c|c|c|c|c|c|c|c|}
\hline \multirow{2}{*}{$\begin{array}{c}\text { Type } \\
\text { of Soil }\end{array}$} & \multirow{2}{*}{$\begin{array}{l}\text { Dose } \mathrm{Co}^{2+} \\
\left(\mathrm{mg} \cdot \mathrm{kg}^{-1} \mathrm{~d} . \mathrm{m} .\right. \\
\text { of Soil) }\end{array}$} & \multicolumn{2}{|c|}{ Org } & \multicolumn{2}{|c|}{ Act } & \multicolumn{2}{|c|}{ Fun } \\
\hline & & Sown Soil & $\begin{array}{c}\text { Unsown } \\
\text { Soil }\end{array}$ & Sown Soil & $\begin{array}{c}\text { Unsown } \\
\text { Soil }\end{array}$ & Sown Soil & $\begin{array}{l}\text { Unsown } \\
\text { Soil }\end{array}$ \\
\hline \multirow{2}{*}{ ls } & 20 & $-0.207^{b}$ & $-0.167^{b}$ & $-0.146^{c}$ & $-0.201^{\mathrm{d}}$ & $-0.382^{d}$ & $-0.263^{d}$ \\
\hline & 80 & $-0.499^{a}$ & $-0.276^{\mathrm{a}}$ & $-0.204^{b}$ & $-0.258^{b}$ & $-0.603^{c}$ & $-0.503^{b}$ \\
\hline \multirow{2}{*}{$\mathrm{scl}$} & 20 & $-0.059 \mathrm{~d}$ & $-0.094^{d}$ & $-0.043^{d}$ & $-0.129^{c}$ & $-0.630^{b}$ & $-0.410^{c}$ \\
\hline & 80 & $-0.145^{c}$ & $-0.103^{c}$ & $-0.222^{\mathrm{a}}$ & $-0.365^{a}$ & $-0.641^{\mathrm{a}}$ & $-0.815^{a}$ \\
\hline
\end{tabular}

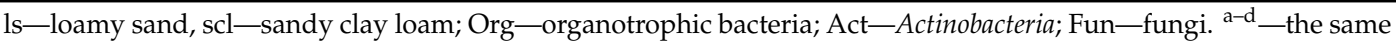
letters for microorganisms in columns are assigned to the same homogeneous groups.

The effect of sorbents was used to calculate the index of effect for the Bio.Zeo.S.0 zeolite $\left(I F_{z}\right)$ and the molecular sieve $\left(I F_{s}\right)$ with respect to the microorganism count. The negative effect of cobalt was slightly mitigated by zeolite (Table 7).

The positive effects of this sorbent on the biological life of soil were observed in sandy clay loam, both in the soil sown with maize and in the unsown soil. This was particularly visible in the case of uncontaminated objects and objects with $20 \mathrm{mg} \mathrm{Co}^{2+} \mathrm{kg}^{-1}$ of soil. Analyzing the manner of use, the application of the zeolite resulted in a smaller negative effect of metal in objects with plant cover. The index of molecular sieve effect $\left(I F_{s}\right)$ on the microorganism count showed a less negative effect of the metal on the microbiological life of the soil (Table 8). In the objects with maize sown in them, the count of the tested groups of microorganisms was higher than in the objects without maize sown on them. As with the zeolite, the count of the microorganisms under the study was higher in sandy clay loam than in loamy sand. 
Table 7. Index of zeolite effect $\left(I F_{z}\right)$ on the microorganism count in soil.

\begin{tabular}{|c|c|c|c|c|c|c|c|}
\hline \multirow{2}{*}{$\begin{array}{l}\text { Type } \\
\text { of Soil }\end{array}$} & \multirow{2}{*}{$\begin{array}{l}\text { Dose } \mathrm{Co}^{2+} \\
\left(\mathrm{mg} \cdot \mathrm{kg}^{-1} \mathrm{~d} . \mathrm{m} .\right. \\
\text { of Soil) }\end{array}$} & \multicolumn{2}{|c|}{ Org } & \multicolumn{2}{|c|}{ Act } & \multicolumn{2}{|c|}{ Fun } \\
\hline & & Sown Soil & $\begin{array}{l}\text { Unsown } \\
\text { Soil }\end{array}$ & Sown Soil & $\begin{array}{l}\text { Unsown } \\
\text { Soil }\end{array}$ & Sown Soil & $\begin{array}{c}\text { Unsown } \\
\text { Soil }\end{array}$ \\
\hline \multirow{3}{*}{ ls } & 0 & $-0.062^{\mathrm{d}}$ & $-0.054^{\mathrm{e}}$ & $-0.079^{d}$ & $-0.387^{\mathrm{e}}$ & $-0.108^{e}$ & $-0.291^{\mathrm{e}}$ \\
\hline & 20 & $-0.366^{f}$ & $-0.005^{c}$ & $0.028^{b}$ & $-0.288^{d}$ & $0.200^{c}$ & $-0.356^{f}$ \\
\hline & 80 & $-0.129 \mathrm{e}$ & $-0.023^{d}$ & $-0.092^{\mathrm{e}}$ & $-0.266^{c}$ & -0.075 & $-0.048^{\mathrm{d}}$ \\
\hline \multirow{3}{*}{$\mathrm{scl}$} & 0 & $0.567^{\mathrm{a}}$ & $0.139^{a}$ & $0.101^{a}$ & $0.321^{\mathrm{a}}$ & $0.073^{\mathrm{d}}$ & $0.241^{b}$ \\
\hline & 20 & $0.409^{b}$ & $0.120^{b}$ & $-0.187^{\mathrm{f}}$ & $0.031^{b}$ & $1.702^{\mathrm{a}}$ & $0.258^{b}$ \\
\hline & 80 & $-0.003^{c}$ & $-0.237^{f}$ & $-0.056^{c}$ & $-0.687^{f}$ & $1.017^{b}$ & $2.815^{\mathrm{a}}$ \\
\hline
\end{tabular}

Explanations under Table 6.

Table 8. Index of molecular sieve effect $\left(I F_{s}\right)$ on the microorganism count in soil.

\begin{tabular}{|c|c|c|c|c|c|c|c|}
\hline \multirow{2}{*}{$\begin{array}{c}\text { Type } \\
\text { of Soil }\end{array}$} & \multirow{2}{*}{$\begin{array}{c}\text { Dose } \mathrm{Co}^{2+} \\
\left(\mathrm{mg} \cdot \mathrm{kg}^{-1} \mathrm{~d} . \mathrm{m} .\right. \\
\text { of Soil) }\end{array}$} & \multicolumn{2}{|c|}{ Org } & \multicolumn{2}{|c|}{ Act } & \multicolumn{2}{|c|}{ Fun } \\
\hline & & Sown Soil & $\begin{array}{c}\text { Unsown } \\
\text { Soil }\end{array}$ & Sown Soil & $\begin{array}{c}\text { Unsown } \\
\text { Soil }\end{array}$ & Sown Soil & $\begin{array}{c}\text { Unsown } \\
\text { Soil }\end{array}$ \\
\hline \multirow{3}{*}{ ls } & 0 & $0.583^{c}$ & $0.397^{c}$ & $0.197^{a}$ & $0.297^{c}$ & $0.241^{\mathrm{f}}$ & $0.893^{\mathrm{d}}$ \\
\hline & 20 & $0.258^{d}$ & $0.293^{\mathrm{e}}$ & $0.184^{b}$ & $0.088^{e}$ & $0.454^{\mathrm{d}}$ & $0.663^{\mathrm{e}}$ \\
\hline & 80 & $0.043^{\mathrm{e}}$ & $-0.007^{f}$ & $0.164^{c}$ & $0.059^{f}$ & $0.907^{c}$ & $1.013^{\mathrm{b}}$ \\
\hline \multirow{3}{*}{ scl } & 0 & $0.993^{\mathrm{a}}$ & $1.148^{\mathrm{a}}$ & $0.102^{d}$ & $0.368^{b}$ & $0.312^{\mathrm{d}}$ & $0.921^{c}$ \\
\hline & 20 & $0.582^{c}$ & $0.417^{b}$ & $-0.180^{f}$ & $0.549^{a}$ & $1.900^{\mathrm{a}}$ & $-0.069^{f}$ \\
\hline & 80 & $0.611^{b}$ & $0.374^{\mathrm{d}}$ & $0.002^{\mathrm{e}}$ & $0.157^{\mathrm{d}}$ & $1.071^{\mathrm{b}}$ & $1.735^{\mathrm{a}}$ \\
\hline
\end{tabular}

Explanations under Table 6.

\subsection{Enzymatic Activity}

The dose of cobalt in the experiment determined up to 35\% of enzyme activity (dehydrogenases), the sorbent addition-3\% (urease), soil type-91\% (alkaline phosphatase), manner of use-up to $30 \%$ (acid phosphatase), and the date of analysis - up to $47 \%$ ( $\beta$-glucosidase). Table 9 presents the enzyme activity in the non-contaminated soil. The enzyme activity, similar to the microbial count, was higher in both soils sown with maize. The enzyme activity was higher in the sandy-clay soil (except for acid phosphatase) than in the loamy sand.

Table 9. Enzyme activity in non-contaminated soil.

\begin{tabular}{|c|c|c|c|c|c|c|c|}
\hline \multirow{2}{*}{ Soil Use } & \multirow{2}{*}{$\begin{array}{c}\text { Deh } \\
\mu \mathrm{mol} \text { TFF } \mathrm{kg}^{-1} \\
\text { d.m. of Soil h} \mathbf{~}^{-1}\end{array}$} & \multirow{2}{*}{$\begin{array}{c}\text { Cat } \\
\text { mol O }{ }_{2} \mathbf{k g}^{-1} \\
\text { d.m. of Soil h-1 }\end{array}$} & \multirow{2}{*}{$\begin{array}{c}\text { Ure } \\
\text { mmol N-NH } \mathrm{kg}^{-1} \text { d.m. } \\
\text { of Soil h} \mathrm{h}^{-1}\end{array}$} & Pac & Pal & Glu & Aryl \\
\hline & & & & \multicolumn{4}{|c|}{ mmol PN kg ${ }^{-1}$ d.m. of Soil h ${ }^{-1}$} \\
\hline \multicolumn{8}{|c|}{ Loamy sand } \\
\hline Sown soil & 4.379 & 0.165 & 0.259 & 1.394 & 0.535 & 1.202 & 0.014 \\
\hline Unsown soil & 3.859 & 0.144 & 0.249 & 1.218 & 0.336 & 0.911 & 0.013 \\
\hline \multicolumn{8}{|c|}{ Sandy clay loam } \\
\hline Sown soil & 6.648 & 0.345 & 0.382 & 1.168 & 2.054 & 2.023 & 0.032 \\
\hline Unsown soil & 6.250 & 0.321 & 0.437 & 0.852 & 1.816 & 1.893 & 0.032 \\
\hline
\end{tabular}

Principal component analysis (PCA) indicated that cobalt inhibited the activity of soil enzymes (Figure 3a,b). The enzyme activity was the highest in the soil uncontaminated with cobalt. With the introduction of cobalt into the soil, their activity decreased, which was indicated by the linear dependence of the projection of cases relative to the position of vectors describing enzymes. The mutual position of vectors also indicated similarity of the reactions of dehydrogenases, catalase, urease, 
acid phosphatase, alkaline phosphatase, $\beta$-glucosidase, and arylsulfatase to the factors under study. In addition, the distribution of cases relative to the vectors suggested that the sorbents added to the soil contributed to the alleviation of stress caused by the presence of cobalt in the soil. The index of the cobalt effect $\left(I F_{C_{0}}\right)$ on the enzyme activity confirmed the negative effect of the metal on the soil biochemical properties (Table 10). Dehydrogenases were found to be the most sensitive to cobalt, whereas $\beta$-glucosidase showed the highest resistance to this metal. The activity of the soil enzymes in loamy sand was lower than in sandy clay loam.

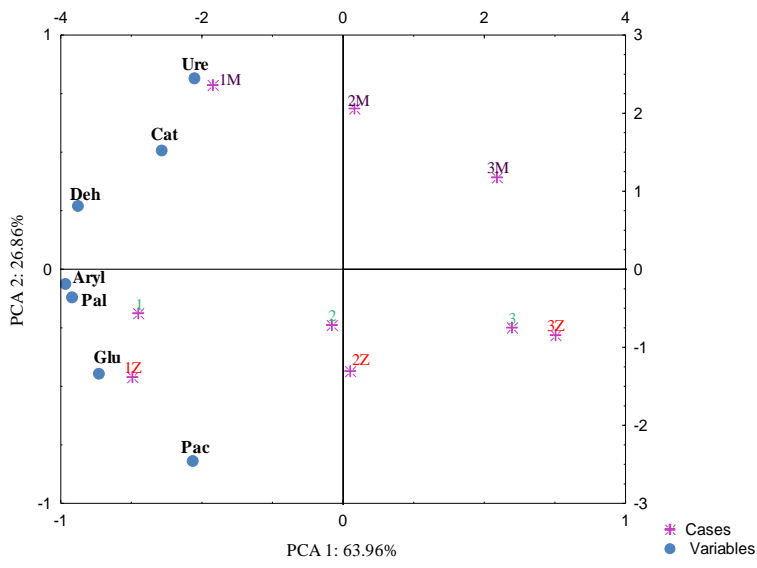

(a)

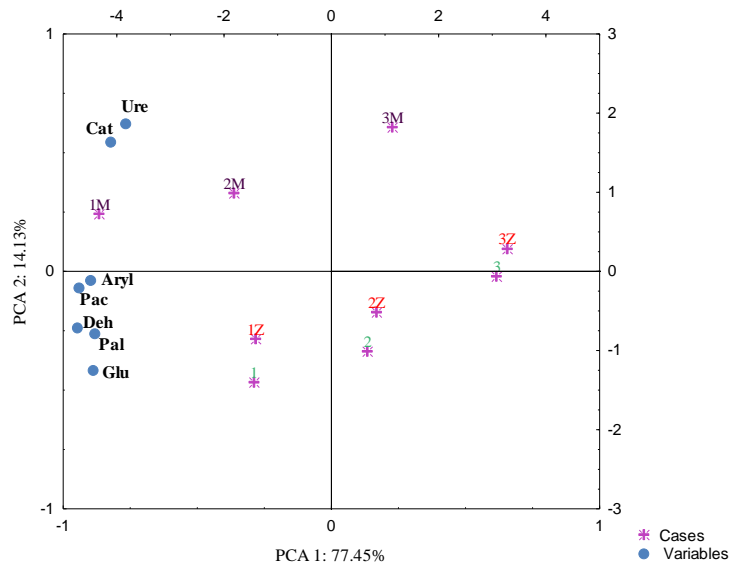

(b)

Figure 3. Activity of enzymes in soil contaminated with cobalt; (a) loamy sand; (b) sandy clay loam; Deh-dehydrogenases; Cat—catalase; Ure-urease; Pac-acid phosphatase; Pal—alkaline phosphatase; Glu- $\beta$-glucosidase; Aryl—arylsulfatase; Dose $\mathrm{Co}^{2+} \mathrm{mg} \cdot \mathrm{kg}^{-1} \mathrm{~d} . \mathrm{m}$. of soil: $1-0$; 2-20; 3-80; Z-zeolite Bio.Zeo.S.01; M-molecular sieve.

Table 10. Index of cobalt effect $\left(I F_{C_{0}}\right)$ on the enzyme activity.

\begin{tabular}{|c|c|c|c|c|c|c|c|c|}
\hline $\begin{array}{c}\text { Type of } \\
\text { Soil }\end{array}$ & $\begin{array}{c}\text { Dose } \mathrm{Co}^{2+} \\
\text { (mg. } \mathrm{kg}^{-1} \mathrm{~d} . \mathrm{m} . \\
\text { of Soil) }\end{array}$ & Deh & Cat & Ure & Pac & Pal & Glu & Aryl \\
\hline \multirow{6}{*}{ ls } & \multicolumn{8}{|c|}{ Unsown soil } \\
\hline & 20 & $-0.080^{b}$ & $-0.063^{b}$ & $-0.432^{a}$ & $-0.115^{b}$ & $-0.095^{b}$ & $-0.105^{b}$ & $-0.167^{b}$ \\
\hline & 80 & $-0.192^{a}$ & $-0.115^{a}$ & $-0.588^{b}$ & $-0.183^{a}$ & $-0.307^{a}$ & $-0.143^{a}$ & $-0.292^{a}$ \\
\hline & \multicolumn{8}{|c|}{ Sown soil } \\
\hline & 20 & $-0.081^{b}$ & $-0.182^{b}$ & $-0.352^{b}$ & $-0.138^{b}$ & $-0.115^{b}$ & $-0.283^{b}$ & $-0.107^{b}$ \\
\hline & 80 & $-0.233^{a}$ & $-0.206^{a}$ & $-0.586^{a}$ & $-0.243^{a}$ & $-0.329^{a}$ & $-0.369^{a}$ & $-0.250^{a}$ \\
\hline \multirow{6}{*}{$\mathrm{scl}$} & \multicolumn{8}{|c|}{ Unsown soil } \\
\hline & 20 & $-0.080^{b}$ & $-0.098^{b}$ & $-0.220^{b}$ & $-0.081^{b}$ & $-0.088^{b}$ & $-0.069^{b}$ & $-0.078^{b}$ \\
\hline & 80 & $-0.173^{a}$ & $-0.129^{a}$ & $-0.290^{a}$ & $-0.159^{a}$ & $-0.131^{a}$ & $-0.129^{a}$ & $-0.125^{a}$ \\
\hline & \multicolumn{8}{|c|}{ Sown soil } \\
\hline & 20 & $-0.012^{b}$ & $-0.081^{b}$ & $-0.058^{b}$ & $-0.077^{b}$ & $-0.054^{b}$ & $-0.037^{b}$ & $-0.078^{b}$ \\
\hline & 80 & $-0.076^{\mathrm{a}}$ & $-0.139^{a}$ & $-0.157^{\mathrm{a}}$ & $-0.178^{a}$ & $-0.219^{a}$ & $-0.089^{a}$ & $-0.203^{a}$ \\
\hline
\end{tabular}

ls—loamy sand, scl—sandy clay loam; Deh—dehydrogenases; Cat—catalase; Ure-urease; Pac—acid phosphatase; $\mathrm{Pal}$-alkaline phosphatase; Glu— $\beta$-glucosidase; Aryl—arylsulfatase. The same letters for microorganisms in columns are assigned to the same homogeneous groups.

The sorbents introduced into the soil alleviated the negative effect of cobalt on enzyme activity to a varying extent. The Bio.Zeo.S.01 alleviated the effect of metal to a small extent (Table 11). Only the arylsulfatase exhibited a positive effect of this sorbent regardless of the factors examined. 
Table 11. Index of zeolite effect $\left(I F_{z}\right)$ on the activity of enzymes in soil.

\begin{tabular}{|c|c|c|c|c|c|c|c|c|}
\hline $\begin{array}{c}\text { Type of } \\
\text { Soil }\end{array}$ & $\begin{array}{l}\text { Dose } \mathrm{Co}^{2+} \\
\left(\mathrm{mg} \cdot \mathrm{kg}^{-1} \mathrm{~d} . \mathrm{m} .\right. \\
\text { of Soil) }\end{array}$ & Deh & Cat & Ure & Pac & Pal & Glu & Aryl \\
\hline \multirow{8}{*}{ ls } & \multicolumn{8}{|c|}{ Unsown soil } \\
\hline & 0 & $0.005^{\mathrm{a}}$ & $-0.181^{b}$ & $-0.171^{\mathrm{c}}$ & $-0.028^{b}$ & $0.079^{c}$ & $0.147^{\mathrm{a}}$ & $0.040^{c}$ \\
\hline & 20 & $-0.066^{\mathrm{c}}$ & $-0.160^{\mathrm{c}}$ & $-0.021^{b}$ & $-0.023^{c}$ & $0.157^{\mathrm{b}}$ & $-0.017^{\mathrm{b}}$ & $0.100^{a}$ \\
\hline & 80 & $-0.011^{b}$ & $-0.331^{\mathrm{a}}$ & $0.112^{\mathrm{a}}$ & $-0.094^{a}$ & $0.217^{\mathrm{a}}$ & $-0.391^{c}$ & $0.063^{b}$ \\
\hline & \multicolumn{8}{|c|}{ Sown soil } \\
\hline & 0 & $0.049^{\mathrm{a}}$ & $-0.227^{a}$ & $-0.021^{\mathrm{c}}$ & $-0.037^{c}$ & $0.081^{\mathrm{a}}$ & $-0.005^{c}$ & $0.071^{a}$ \\
\hline & 20 & $-0.087^{b}$ & $-0.152^{c}$ & $0.263^{b}$ & $0.010^{\mathrm{b}}$ & $-0.019^{b}$ & $0.169^{\mathrm{a}}$ & $0.040^{\mathrm{c}}$ \\
\hline & 80 & $-0.001^{\mathrm{c}}$ & $-0.183^{b}$ & $0.752^{\mathrm{a}}$ & $0.086^{\mathrm{a}}$ & $-0.046^{c}$ & $0.006^{\mathrm{b}}$ & $0.048^{b}$ \\
\hline \multirow{8}{*}{$\mathrm{scl}$} & \multicolumn{8}{|c|}{ Unsown soil } \\
\hline & 0 & $-0.030^{b}$ & $0.003^{b}$ & $-0.321^{\mathrm{a}}$ & $0.065^{\mathrm{b}}$ & $-0.050^{b}$ & $-0.034^{c}$ & $0.094^{a}$ \\
\hline & 20 & $0.009^{c}$ & $0.043^{\mathrm{a}}$ & $-0.242^{c}$ & $0.112^{\mathrm{a}}$ & $-0.031^{c}$ & $-0.015^{b}$ & $0.034^{b}$ \\
\hline & 80 & $-0.045^{\mathrm{a}}$ & $0.002^{c}$ & $-0.253^{b}$ & $0.057^{c}$ & $-0.152^{a}$ & $0.014^{\mathrm{a}}$ & $0.018^{\mathrm{c}}$ \\
\hline & \multicolumn{8}{|c|}{ Sown soil } \\
\hline & 0 & $-0.001^{\mathrm{c}}$ & $-0.044^{\mathrm{c}}$ & $0.545^{\mathrm{a}}$ & $0.008^{c}$ & $-0.062^{b}$ & $-0.043^{a}$ & $0.188^{a}$ \\
\hline & 20 & $-0.050^{\mathrm{a}}$ & $-0.016^{\mathrm{b}}$ & $-0.001^{\mathrm{c}}$ & $0.031^{\mathrm{b}}$ & $-0.170^{a}$ & $-0.032^{b}$ & $0.153^{b}$ \\
\hline & 80 & $-0.044^{\mathrm{b}}$ & $0.015^{\mathrm{a}}$ & $-0.025^{b}$ & $0.097^{\mathrm{a}}$ & $-0.039^{c}$ & $-0.043^{\mathrm{a}}$ & $0.137^{c}$ \\
\hline
\end{tabular}

Explanations under Table 10.

Although the activity of the analyzed enzymes decreased under the influence of cobalt contamination of soil, better effects were visible for the molecular sieve (Table 12). The calculated index of sorbents effect $\left(I F_{s}\right)$ on the enzyme activity was particularly high for urease in the pots sown with maize on both soil types. The effect of the molecular sieve on the activity of other enzymes remained at a similar level and was higher in sandy clay loam, where maize was grown.

Table 12. Index of molecular sieve effect $\left(I F_{s}\right)$ on the activity of enzymes in soil.

\begin{tabular}{|c|c|c|c|c|c|c|c|c|}
\hline $\begin{array}{c}\text { Type of } \\
\text { Soil }\end{array}$ & $\begin{array}{c}\text { Dose } \mathrm{Co}^{2+} \\
\text { (mg. } \mathrm{kg}^{-1} \mathrm{~d} . \mathrm{m} . \text { of } \\
\text { Soil) }\end{array}$ & Deh & Cat & Ure & Pac & Pal & Glu & Aryl \\
\hline \multirow{8}{*}{ ls } & \multicolumn{8}{|c|}{ Unsown soil } \\
\hline & 0 & $0.025^{b}$ & $0.655^{b}$ & $0.203^{c}$ & $0.032^{c}$ & $0.024^{b}$ & $0.099^{a}$ & $0.040^{c}$ \\
\hline & 20 & $0.015^{c}$ & $0.279^{c}$ & $0.887^{\mathrm{a}}$ & $0.050^{b}$ & $0.008^{c}$ & $0.059^{b}$ & $0.050^{b}$ \\
\hline & 80 & $0.074^{\mathrm{a}}$ & $1.071^{\mathrm{a}}$ & $0.746^{\mathrm{b}}$ & $0.059^{a}$ & $0.060^{\mathrm{a}}$ & $0.019^{c}$ & $0.063^{a}$ \\
\hline & \multicolumn{8}{|c|}{ Sown soil } \\
\hline & 0 & $0.001^{c}$ & $0.021^{c}$ & $0.867^{c}$ & $0.022^{b}$ & $0.012^{c}$ & $0.023^{c}$ & $0.036^{c}$ \\
\hline & 20 & $0.009^{b}$ & $0.219^{b}$ & $1.430^{b}$ & $0.042^{\mathrm{a}}$ & $0.019^{b}$ & $0.031^{b}$ & $0.040^{b}$ \\
\hline & 80 & $0.138^{a}$ & $0.340^{\mathrm{a}}$ & $1.678^{\mathrm{a}}$ & $0.009^{c}$ & $0.100^{\mathrm{a}}$ & $0.033^{a}$ & $0.095^{\mathrm{a}}$ \\
\hline \multirow{8}{*}{$\mathrm{scl}$} & \multicolumn{8}{|c|}{ Unsown soil } \\
\hline & 0 & $0.022^{\mathrm{a}}$ & $0.176^{c}$ & $0.830^{\mathrm{a}}$ & $0.121^{\mathrm{c}}$ & $0.039^{a}$ & $0.009^{b}$ & $0.016^{c}$ \\
\hline & 20 & $0.018^{b}$ & $0.232^{b}$ & $0.510^{\mathrm{b}}$ & $0.132^{\mathrm{a}}$ & $0.030^{b}$ & $0.004^{\mathrm{c}}$ & $0.051^{\mathrm{a}}$ \\
\hline & 80 & $0.003^{c}$ & $0.240^{\mathrm{a}}$ & $0.482^{\mathrm{c}}$ & $0.125^{b}$ & $0.028^{c}$ & $0.028^{a}$ & $0.018^{\mathrm{b}}$ \\
\hline & \multicolumn{8}{|c|}{ Sown soil } \\
\hline & 0 & $0.132^{\mathrm{a}}$ & $0.200^{c}$ & $1.689^{\mathrm{a}}$ & $0.100^{\mathrm{a}}$ & $0.023^{b}$ & 0.019 & $0.313^{a}$ \\
\hline & 20 & $0.103^{b}$ & $0.274^{\mathrm{a}}$ & $1.565^{\mathrm{c}}$ & $0.091^{b}$ & $0.015^{c}$ & 0.010 & $0.203^{c}$ \\
\hline & 80 & $0.065^{\mathrm{c}}$ & $0.246^{b}$ & $1.647^{b}$ & $0.042^{c}$ & $0.105^{\mathrm{a}}$ & 0.031 & $0.255^{b}$ \\
\hline
\end{tabular}

Explanations under Table 10. 


\subsection{Plant Yield and Cobalt Content}

Maize grown on both soils was also not resistant to the negative effects of cobalt because the yield of its above-ground parts and roots decreased under the influence of this metal (Table 13). A higher yield of above-ground parts and roots of maize was observed in sandy clay loam compared to loamy sand. The molecular sieve had a better effect than the Bio.Zeo.S.01 zeolite, which resulted in the maize yield.

Table 13. The yield of above-ground parts and roots ( $\mathrm{g}$ d.m. pot $\left.^{-1}\right)$ of maize from soil contaminated with cobalt with the addition of zeolite and a molecular sieve.

\begin{tabular}{|c|c|c|c|c|}
\hline \multirow{2}{*}{$\begin{array}{c}\text { Dose } \mathrm{Co}^{2+} \\
\left(\mathrm{mg} \cdot \mathrm{kg}^{-1} \mathrm{~d} \cdot \mathrm{m} .\right. \\
\text { of Soil) }\end{array}$} & \multicolumn{2}{|c|}{ Loamy Sand } & \multicolumn{2}{|c|}{ Sandy Clay Loam } \\
\hline & $\begin{array}{c}\text { Above-Ground } \\
\text { Parts }\end{array}$ & Roots & $\begin{array}{c}\text { Above-Ground } \\
\text { Parts }\end{array}$ & Roots \\
\hline \multicolumn{5}{|c|}{ No sorbents } \\
\hline 0 & $41.95^{\mathrm{a}}$ & $8.00^{\mathrm{a}}$ & $53,87^{a}$ & $8.90^{a}$ \\
\hline 20 & $39.88^{b}$ & $7.00^{b}$ & $53.84^{b}$ & $8.70^{\mathrm{b}}$ \\
\hline 80 & $36.00^{c}$ & $5.68^{c}$ & $39.66^{\mathrm{c}}$ & $8.18^{c}$ \\
\hline \multicolumn{5}{|c|}{ Zeolite Bio.Zeo.S.01 } \\
\hline 0 & $44.02^{\mathrm{a}}$ & $6.00^{\mathrm{b}}$ & $54.19^{a}$ & $8.80^{\mathrm{a}}$ \\
\hline 20 & $43.65^{b}$ & $7.13^{a}$ & $51.25^{\mathrm{b}}$ & $8.70^{\mathrm{b}}$ \\
\hline 80 & $31.54^{\mathrm{c}}$ & $5.73^{c}$ & $35.57^{c}$ & $6.60^{c}$ \\
\hline \multicolumn{5}{|c|}{ Molecular sieve } \\
\hline 0 & $44.93^{a}$ & $11.90^{\mathrm{a}}$ & $56.70^{a}$ & $11.60^{\mathrm{a}}$ \\
\hline 20 & $43.65^{b}$ & $8.55^{\mathrm{b}}$ & $53.36^{\mathrm{b}}$ & $11.60^{\mathrm{a}}$ \\
\hline 80 & $39.51^{c}$ & $7.10^{\mathrm{c}}$ & $50.23^{c}$ & $9.10^{\mathrm{b}}$ \\
\hline
\end{tabular}

The same letters for microorganisms in columns are assigned to the same homogeneous groups.

The largest increase in cobalt content in the soil, regardless of the additives, was recorded in sandy clay loam (Table 14). The opposite effect was observed for the above-ground parts and roots, as the content of this metal in the plant material was higher in maize cultivated on a loamy sand. For additives, a higher content of cobalt was observed in the objects with zeolite Bio.Zeo.S.01, regardless of the soil or plant material.

Table 14. Cobalt content in the soil, above-ground parts, and roots of maize $\left(\mathrm{mg} \cdot \mathrm{kg}^{-1} \mathrm{~d} . \mathrm{m}\right.$.).

\begin{tabular}{|c|c|c|c|c|c|c|}
\hline \multirow{2}{*}{$\begin{array}{c}\text { Dose } \mathrm{Co}^{2+} \\
\left(\mathrm{mg} \cdot \mathrm{kg}^{-1}\right. \\
\text { d.m. of Soil) }\end{array}$} & \multicolumn{3}{|c|}{ Loamy Sand } & \multicolumn{3}{|c|}{ Sandy Clay Loam } \\
\hline & Soil & $\begin{array}{c}\text { Above-Ground } \\
\text { Parts }\end{array}$ & Roots & Soil & $\begin{array}{c}\text { Above-Ground } \\
\text { Parts }\end{array}$ & Roots \\
\hline \multicolumn{7}{|c|}{ No sorbents } \\
\hline 0 & $3.33^{b}$ & $0.50^{\mathrm{b}}$ & $3.32^{b}$ & $5.19^{b}$ & $0.50^{b}$ & $3.73^{b}$ \\
\hline 80 & $53.55^{\mathrm{a}}$ & $3.78^{\mathrm{a}}$ & $230.11^{\mathrm{a}}$ & $79.83^{a}$ & $0.86^{\mathrm{a}}$ & $190.16^{a}$ \\
\hline \multicolumn{7}{|c|}{ Zeolite Bio.Zeo.S.01 } \\
\hline 0 & $3.60^{b}$ & $0.50^{b}$ & $1.88^{\mathrm{b}}$ & $6.19^{b}$ & $0.50^{b}$ & $2.37^{\mathrm{b}}$ \\
\hline 80 & $56.84^{\mathrm{a}}$ & $3.40^{\mathrm{a}}$ & $342.55^{\mathrm{a}}$ & $65.27^{\mathrm{a}}$ & $0.87^{\mathrm{a}}$ & $198.70^{a}$ \\
\hline \multicolumn{7}{|c|}{ Molecular sieve } \\
\hline 0 & $3.65^{b}$ & $0.61^{\mathrm{b}}$ & $2.60^{b}$ & $5.20^{\mathrm{b}}$ & $0.42^{b}$ & $29.35^{b}$ \\
\hline 80 & $54.90^{\mathrm{a}}$ & $1.45^{\mathrm{a}}$ & $119.18^{a}$ & $82.21^{\mathrm{a}}$ & $0.79^{a}$ & $95.57^{\mathrm{a}}$ \\
\hline
\end{tabular}


It was calculated from the yield and cobalt content in the above-ground parts and roots of maize how much of this metal taken up by the plant (Table 15). Cobalt at a dose of $80 \mathrm{mg} \cdot \mathrm{kg}^{-1} \mathrm{caused}$ its greater accumulation in the plant in loamy sand and sandy clay loam, both in objects with and without the addition of sorbents. The zeolite Bio.Zeo.S.01 caused a higher uptake of this metal by maize compared to the molecular sieve. A higher accumulation of this element was observed in maize roots than in the above-ground parts of maize (Table 15). Lower redistribution in the aboveground parts of maize was observed in the soil, regardless of the type of sorbent, into which the cobalt was introduced at a rate of $80 \mathrm{mg} \cdot \mathrm{kg}^{-1}$. The opposite effect was observed in roots. An addition of sorbents, especially zeolite, increased the redistribution of this metal in the plant. Taking into account the soil type, revealed a higher accumulation of this element in maize cultivated on loamy sand. Considering the cobalt content in the above-ground parts and roots of maize, a bioconcentration index $\left(I B_{C_{0}}\right)$ was calculated, which showed a higher concentration of this metal in uncontaminated soil (Table 15). Higher values of this index were observed in loamy sand than in sandy clay loam.

Table 15. Absorption, redistribution, and bioconcentration of cobalt in a plant.

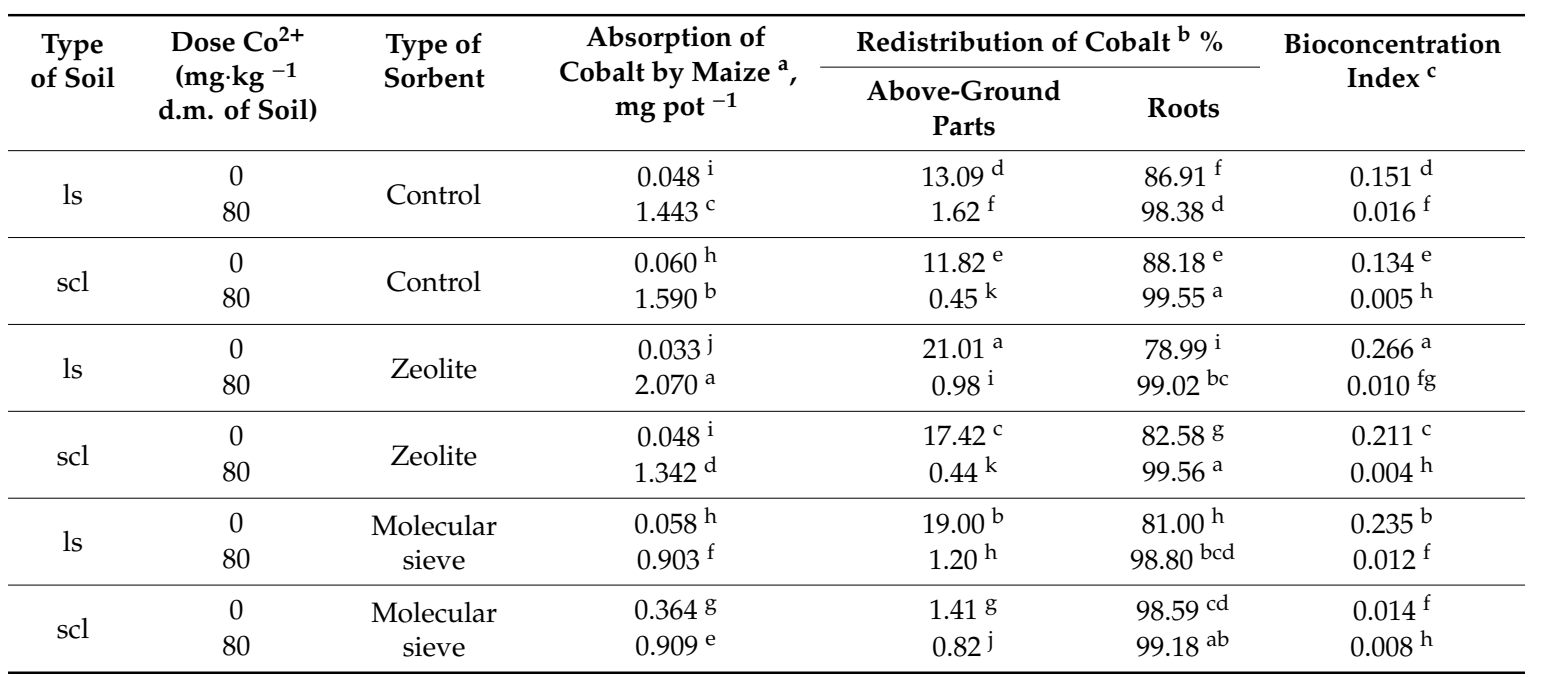

ls-loamy sand, scl—sandy clay loam. The same letters for microorganisms in columns are assigned to the same homogeneous groups. ${ }^{\text {a }}$ Absorption: The sum of the product of above-ground parts yield and cobalt content in the above-ground parts of maize and the product of root yield and cobalt content in roots; ${ }^{\mathrm{b}}$ Cobalt redistribution in above-ground parts: The ratio of the sum of cobalt content in above-ground parts and roots and cobalt content in above-ground parts, Cobalt redistribution in roots: The ratio of the sum of cobalt content in above-ground parts and roots and cobalt content in roots; ${ }^{\mathrm{c}}$ Bioconcentration index: The ratio of cobalt content in above-ground parts and cobalt content in roots of maize.

\subsection{Chemical Properties of Soil}

The addition of zeolite and molecular sieve to the soil had little effect on the physicochemical properties of the soil (Tables 16 and 17). 
Table 16. Physicochemical properties of loamy sand, contaminated with cobalt, with the addition of a molecular sieve and zeolite.

\begin{tabular}{|c|c|c|c|c|c|c|c|}
\hline \multirow{2}{*}{$\begin{array}{c}\text { Dose } \mathrm{Co}^{2+} \\
\left(\mathrm{mg} \cdot \mathrm{kg}^{-1} \text { d.m. of Soil) }\right.\end{array}$} & \multirow[t]{2}{*}{$\mathrm{pH}_{\mathrm{KCl}}$} & $C_{\text {org }}$ & $\mathbf{N}_{\text {total }}$ & HAC & EBC & CEC & \multirow{2}{*}{$\begin{array}{l}\text { BS } \\
(\%)\end{array}$} \\
\hline & & \multicolumn{2}{|c|}{$\mathrm{g} \cdot \mathrm{kg}^{-1}$ d.m. Soil } & \multicolumn{3}{|c|}{$\mathrm{mmol}^{(+)} \cdot \mathrm{kg}^{-1}$ d.m. Soil } & \\
\hline \multicolumn{8}{|c|}{ Sown soil } \\
\hline \multicolumn{8}{|c|}{ No sorbents } \\
\hline 0 & $7.07^{\mathrm{a}}$ & $6.10^{a}$ & $0.70^{\mathrm{a}}$ & $7.88^{c}$ & $85.00^{a}$ & $92.88^{a}$ & $91.50^{a}$ \\
\hline 20 & $6.77^{b}$ & $5.65^{b}$ & $0.70^{\mathrm{a}}$ & $8.00^{b}$ & $81.67^{b}$ & $89.67^{b}$ & $91.07^{b}$ \\
\hline 80 & $6.70^{c}$ & $5.30^{\mathrm{c}}$ & $0.70^{\mathrm{a}}$ & $8.25^{\mathrm{a}}$ & $77.17^{\mathrm{c}}$ & $85.42^{c}$ & $90.33^{c}$ \\
\hline \multicolumn{8}{|c|}{ Zeolite Bio.Zeo.S.01 } \\
\hline 0 & $6.87^{\mathrm{a}}$ & $6.05^{a}$ & $0.08^{a}$ & $9.95^{c}$ & $85.50^{a}$ & $95.45^{\mathrm{a}}$ & $89.51^{a}$ \\
\hline 20 & $6.83^{b}$ & $5.70^{\mathrm{b}}$ & $0.70^{\mathrm{b}}$ & $10.25^{b}$ & $84.33^{b}$ & $94.58^{b}$ & $89.15^{b}$ \\
\hline 80 & $6.77^{c}$ & $5.60^{c}$ & $0.70^{\mathrm{b}}$ & $10.75^{a}$ & $80.33^{c}$ & $91.08^{c}$ & $88.18^{c}$ \\
\hline \multicolumn{8}{|c|}{ Molecular sieve } \\
\hline 0 & $7.17^{\mathrm{a}}$ & $5.70^{a}$ & $0.80^{\mathrm{a}}$ & $9.20^{c}$ & $70.83^{a}$ & $80.03^{a}$ & $88.49^{a}$ \\
\hline 20 & $7.13^{b}$ & $5.40^{\mathrm{b}}$ & $0.70^{\mathrm{b}}$ & $9.63^{b}$ & $70.17^{b}$ & $79.79^{b}$ & $87.92^{b}$ \\
\hline 80 & $6.87^{c}$ & $5.35^{c}$ & $0.60^{c}$ & $9.88^{\mathrm{a}}$ & $68.50^{c}$ & $78.38^{c}$ & $87.35^{c}$ \\
\hline \multicolumn{8}{|c|}{ Unsown soil } \\
\hline \multicolumn{8}{|c|}{ No sorbents } \\
\hline 0 & $6.73^{a}$ & $6.25^{\mathrm{a}}$ & $0.79^{a}$ & $7.75^{c}$ & $81.67^{a}$ & $89.42^{a}$ & $91.33^{a}$ \\
\hline 20 & $6.27^{\mathrm{b}}$ & $5.65^{b}$ & $0.70^{\mathrm{b}}$ & $7.88^{b}$ & $78.33^{b}$ & $86.21^{b}$ & $90.86^{b}$ \\
\hline 80 & $6.27^{b}$ & $5.60^{c}$ & $0.70^{\mathrm{b}}$ & $8.13^{a}$ & $73.83^{c}$ & $81.96^{c}$ & $90.07^{c}$ \\
\hline \multicolumn{8}{|c|}{ Zeolite Bio.Zeo.S.01 } \\
\hline 0 & $6.73^{a}$ & $5.95^{\mathrm{a}}$ & $0.90^{\mathrm{a}}$ & $9.63^{b}$ & $82.17^{a}$ & $91.79^{\mathrm{a}}$ & $89.48^{a}$ \\
\hline 20 & $6.57^{\mathrm{b}}$ & $5.45^{\mathrm{b}}$ & $0.70^{\mathrm{b}}$ & $9.63^{b}$ & $81.00^{\mathrm{b}}$ & $90.63^{b}$ & $89.37^{b}$ \\
\hline 80 & $6.53^{c}$ & $5.40^{\mathrm{c}}$ & $0.70^{\mathrm{b}}$ & $10.50^{\mathrm{a}}$ & $77.00^{c}$ & $87.50^{c}$ & $87.99^{c}$ \\
\hline \multicolumn{8}{|c|}{ Molecular sieve } \\
\hline 0 & $7.07^{\mathrm{a}}$ & $5.65^{a}$ & $0.80^{a}$ & $8.38^{c}$ & $67.50^{a}$ & $75.88^{b}$ & $88.96^{a}$ \\
\hline 20 & $7.03^{b}$ & $5.55^{\mathrm{b}}$ & $0.70^{b}$ & $9.25^{\mathrm{a}}$ & $66.83^{b}$ & $76.08^{a}$ & $87.81^{b}$ \\
\hline 80 & $7.03^{b}$ & $5.25^{c}$ & $0.70^{\mathrm{b}}$ & $9.13^{b}$ & $65.17^{c}$ & $74.29^{c}$ & $87.70^{c}$ \\
\hline
\end{tabular}

$\mathrm{C}_{\text {org }}$-total organic carbon; $\mathrm{N}_{\text {total }}$-total nitrogen; HAC—hydrolytic acidity; EBC—total exchangeable cations; CEC - total exchange capacity of soil; BS—basic cations saturation ratio in the soil; $\mathrm{mmol}^{(+)}$- sorption of one " +" ion charge. The same letters for microorganisms in columns are assigned to the same homogeneous groups. 
Table 17. Physicochemical properties of sandy clay loam, contaminated with cobalt, with the addition of a molecular sieve and zeolite.

\begin{tabular}{|c|c|c|c|c|c|c|c|}
\hline \multirow{2}{*}{$\begin{array}{c}\text { Dose } \mathrm{Co}^{2+} \\
\left(\mathrm{mg} \cdot \mathrm{kg}^{-1} \text { d.m. of Soil) }\right.\end{array}$} & \multirow[t]{2}{*}{$\mathrm{pH}_{\mathrm{KCl}}$} & $C_{\text {org }}$ & $\mathbf{N}_{\text {total }}$ & HAC & EBC & CEC & \multirow{2}{*}{$\begin{array}{l}\text { BS } \\
(\%)\end{array}$} \\
\hline & & \multicolumn{2}{|c|}{$\mathrm{g} \cdot \mathrm{kg}^{-1}$ d.m. Soil } & \multicolumn{3}{|c|}{$\mathrm{mmol}^{(+)} \cdot \mathrm{kg}^{-1}$ d.m. Soil } & \\
\hline \multicolumn{8}{|c|}{ Sown soil } \\
\hline \multicolumn{8}{|c|}{ No sorbents } \\
\hline 0 & $7.13^{a}$ & $13.60^{\mathrm{a}}$ & $1.30^{\mathrm{a}}$ & $6.50^{c}$ & $124.17^{\mathrm{a}}$ & $130.67^{a}$ & $95.02^{a}$ \\
\hline 20 & $7.07^{b}$ & $13.35^{\mathrm{b}}$ & $1.10^{b}$ & $6.88^{b}$ & $120.33^{b}$ & $127.21^{b}$ & $94.59^{b}$ \\
\hline 80 & $7.07^{b}$ & $13.15^{c}$ & $1.00^{\mathrm{c}}$ & $7.00^{\mathrm{a}}$ & $117.83^{c}$ & $124.83^{c}$ & $94.39^{c}$ \\
\hline \multicolumn{8}{|c|}{ Zeolite Bio.Zeo.S.01 } \\
\hline 0 & $7.07^{\mathrm{a}}$ & $13.80^{\mathrm{a}}$ & $1.20^{\mathrm{a}}$ & $8.50^{c}$ & $127.50^{\mathrm{a}}$ & $136.00^{\mathrm{a}}$ & $93.75^{a}$ \\
\hline 20 & $6.97^{\mathrm{b}}$ & $13.65^{\mathrm{b}}$ & $1.20^{\mathrm{a}}$ & $10.50^{\mathrm{b}}$ & $125.17^{b}$ & $135.67^{b}$ & $92.26^{b}$ \\
\hline 80 & $6.97^{b}$ & $13.35^{c}$ & $1.10^{\mathrm{b}}$ & $11.00^{\mathrm{a}}$ & $123.50^{c}$ & $134.50^{\mathrm{c}}$ & $91.82^{\mathrm{c}}$ \\
\hline \multicolumn{8}{|c|}{ Molecular sieve } \\
\hline 0 & $7.57^{\mathrm{a}}$ & $13.25^{\mathrm{a}}$ & $1.20^{\mathrm{a}}$ & $8.75^{c}$ & $122.33^{a}$ & $131.08^{a}$ & $93.32^{\mathrm{a}}$ \\
\hline 20 & $7.53^{b}$ & $13.10^{\mathrm{b}}$ & $1.01^{b}$ & $8.88^{b}$ & $118.33^{b}$ & $127.21^{b}$ & $93.02^{b}$ \\
\hline 80 & $7.53^{b}$ & $12.80^{\mathrm{c}}$ & $1.00^{\mathrm{b}}$ & $9.88^{\mathrm{a}}$ & $116.67^{c}$ & $126.54^{c}$ & $92.19^{\mathrm{C}}$ \\
\hline \multicolumn{8}{|c|}{ Unsown soil } \\
\hline \multicolumn{8}{|c|}{ No sorbents } \\
\hline 0 & $6.93^{a}$ & $14.30^{\mathrm{a}}$ & $1.30^{\mathrm{a}}$ & $6.13^{c}$ & $120.83^{a}$ & $126.96^{\mathrm{a}}$ & $95.18^{a}$ \\
\hline 20 & $6.93^{\mathrm{a}}$ & $13.75^{b}$ & $1.20^{b}$ & $6.63^{b}$ & $117.00^{b}$ & $123.63^{b}$ & $94.64^{b}$ \\
\hline 80 & $6.90^{\mathrm{b}}$ & $13.65^{c}$ & $1.20^{\mathrm{b}}$ & $6.88^{\mathrm{a}}$ & $114.50^{\mathrm{c}}$ & $121.38^{c}$ & $94.34^{\mathrm{c}}$ \\
\hline \multicolumn{8}{|c|}{ Zeolite Bio.Zeo.S.01 } \\
\hline 0 & $6.83^{a}$ & $13.70^{\mathrm{a}}$ & $1.30^{\mathrm{a}}$ & $8.38^{c}$ & $124.17^{a}$ & $132.54^{\mathrm{a}}$ & $93.68^{a}$ \\
\hline 20 & $6.83^{a}$ & $12.70^{\mathrm{b}}$ & $1.20^{\mathrm{b}}$ & $10.25^{b}$ & $121.83^{b}$ & $132.08^{b}$ & $92.24^{b}$ \\
\hline 80 & $6.80^{\mathrm{b}}$ & $12.60^{\mathrm{c}}$ & $1.20^{\mathrm{b}}$ & $10.75^{\mathrm{a}}$ & $120.17^{c}$ & $130.92^{c}$ & $91.79^{c}$ \\
\hline \multicolumn{8}{|c|}{ Molecular sieve } \\
\hline 0 & $7.37^{a}$ & $12.95^{\mathrm{a}}$ & $1.30^{\mathrm{a}}$ & $8.38^{c}$ & $119.00^{a}$ & $127.38^{a}$ & $93.42^{\mathrm{a}}$ \\
\hline 20 & $7.33^{b}$ & $12.55^{b}$ & $1.30^{\mathrm{a}}$ & $8.75^{b}$ & $115.00^{b}$ & $123.75^{b}$ & $92.93^{b}$ \\
\hline 80 & $7.33^{c}$ & $12.25^{c}$ & $1.28^{\mathrm{b}}$ & $9.63^{\mathrm{a}}$ & $113.33^{c}$ & $122.96^{\mathrm{c}}$ & $92.17^{\mathrm{c}}$ \\
\hline
\end{tabular}

Explanations under Table 16.

This was particularly evident in the case of soil $\mathrm{pH}$, which decreased with an increase in the amount of this metal in the soil, regardless of the other factors examined. The content of total nitrogen and organic carbon was higher in sandy clay loam than in loamy sand, but it remained at a similar level. As soil contamination with cobalt increased, the hydrolytic acidity increased, and the total alkaline exchangeable cations decreased accordingly.

The calculated coefficients of correlation between a cobalt dose and the microbial count, enzyme activity, plant yield, cobalt content, and physicochemical properties confirmed the adverse effect of cobalt on the biological life of the soil (Tables 18 and 19). In loamy sand and sandy-clay soil, significant negative correlations were observed between a cobalt dose and the microbial count and enzyme activity, and there was a significant positive correlation between the cobalt content and hydrolytic acidity. 
Table 18. Coefficients of correlation between variables in treatments sown with loamy sand.

\begin{tabular}{|c|c|c|c|c|c|c|c|c|c|c|c|c|c|c|c|c|c|c|c|}
\hline $\begin{array}{l}\text { Variable } \\
\text { Factors }\end{array}$ & Yield & $\mathrm{Co}_{\mathrm{av}}$ & Org & Act & Fun & Deh & Cat & Ure & Pac & Pal & Glu & Aryl & $\mathrm{pH}_{\mathrm{KCl}}$ & $C_{\text {org }}$ & $\mathbf{N}_{\text {total }}$ & HAC & EBC & CEC & BS \\
\hline Dose & $-0.929 *$ & $0.860^{*}$ & $-0.996^{*}$ & $-0.980 *$ & $-0.992 *$ & $-0.997^{*}$ & $-0.998 *$ & $-0.999 *$ & $-0.996 *$ & $-0.995^{*}$ & $-0.999 *$ & $-0.914 *$ & $-0.972 *$ & $-0.970 *$ & $-0.976^{*}$ & $0.999 *$ & $-0.983 *$ & $-0.978^{*}$ & -0.994 \\
\hline Yield & & -0.988 * & 0.894 * & 0.837 * & $0.874^{*}$ & 0.898 * & $0.952 *$ & 0.912 * & 0.895 * & $0.960^{*}$ & $0.927 *$ & $0.700^{*}$ & $0.818^{*}$ & 0.811 * & 0.827 * & -0.937 * & $0.982 *$ & $0.986^{*}$ & $0.964 *$ \\
\hline $\mathrm{Co}_{\mathrm{av}}$ & & & $-0.812 *$ & -0.741 * & -0.787 * & $-0.817^{*}$ & -0.892 * & $-0.837^{*}$ & -0.814 * & -0.905 * & -0.857 * & -0.579 & $-0.718^{*}$ & -0.709 * & -0.728 * & $\begin{array}{c}-0.937 \\
0.871 *\end{array}$ & $\begin{array}{c}0.902 \\
-0.940 *\end{array}$ & $\begin{array}{l}0.0 .947 \\
-0.94 \%\end{array}$ & $\begin{array}{c}0.904 \\
-0.911\end{array}$ \\
\hline Org & & & & 0.994 * & $0.999 *$ & $0.999 *$ & $0.988^{*}$ & $0.999 *$ & $0.999 *$ & $0.983 *$ & 0.997 * & $0.946^{*}$ & $0.989^{*}$ & $0.987^{*}$ & 0.991 * & -0.994 * & 0.963 * & 0.956 * & $0.980^{*}$ \\
\hline Act & & & & & $0.997 *$ & $0.993^{*}$ & $0.964 *$ & $0.988 *$ & $0.993 *$ & $0.956 *$ & $0.981 *$ & $0.977^{*}$ & $0.999 *$ & $0.999 *$ & $0.999 *$ & $-0.975 *$ & $0.926^{*}$ & $0.917^{*}$ & $0.952 *$ \\
\hline Fun & & & & & & $0.999 *$ & $0.981 *$ & 0.996 * & $0.999 *$ & $0.975 *$ & $0.992 *$ & $0.959 *$ & $0.994 *$ & 0.993 * & 0.996 * & $-0.989 *$ & 0.951 * & 0.944 * & 0.971 * \\
\hline Deh & & & & & & & $0.989 *$ & 0.999 * & $0.999 *$ & 0.985 * & $0.997^{*}$ & $0.943 *$ & 0.988 * & 0.986 * & 0.990 * & -0.995 * & 0.965 * & 0.959 * & 0.982 * \\
\hline Cat & & & & & & & & $0.994 *$ & 0.989 * & 0.990 * & $0.997 *$ & 0.885 * & 0.955 * & 0.951 * & 0.959 * & $\begin{array}{l}-0.999 * \\
\end{array}$ & 0.993 * & $0.990 *$ & $0.999 *$ \\
\hline Ure & & & & & & & & & 0.999 * & 0.990 * & $0.999 *$ & $0.931 *$ & $0.982 *$ & 0.979 * & 0.985 * & $-0.998 *$ & $0.974 *$ & $0.968^{*}$ & 0.988 * \\
\hline Pac & & & & & & & & & & 0.984 * & $0.997^{*}$ & $0.945^{*}$ & $0.989 *$ & 0.987 * & 0.991 * & -0.994 * & 0.964 * & 0.957 * & $0.981 *$ \\
\hline $\mathrm{Pal}$ & & & & & & & & & & & $0.995 *$ & $0.871 *$ & $0.946^{*}$ & $0.942 *$ & 0.951 * & $-0.997 *$ & 0.996 * & $0.994 *$ & $0.999 *$ \\
\hline Glu & & & & & & & & & & & & 0.916 * & 0.974 * & 0.971 * & 0.977 * & -0.999 * & $0.982 *$ & 0.977 * & 0.993 * \\
\hline Aryl & & & & & & & & & & & & & $0.983 *$ & 0.985 * & 0.980 * & -0.905 * & 0.823 * & 0.810 * & 0.864 * \\
\hline $\mathrm{pH}$ & & & & & & & & & & & & & & $0.999 *$ & $0.999 *$ & $-0.967^{*}$ & $0.913 *$ & $0.903 *$ & 0.941 * \\
\hline $\mathrm{C}_{\mathrm{org}}$ & & & & & & & & & & & & & & & $0.999 *$ & $-0.964 *$ & 0.908 * & $0.898^{*}$ & 0.937 * \\
\hline $\mathrm{N}_{\text {total }}$ & & & & & & & & & & & & & & & & $-0.971 *$ & 0.919 * & 0.910 * & 0.946 * \\
\hline HAC & & & & & & & & & & & & & & & & & -0.987 & -0.983 & -0.996 \\
\hline EBC & & & & & & & & & & & & & & & & & & 0.999 & 0.997 \\
\hline CEC & & & & & & & & & & & & & & & & & & & 0.995 \\
\hline
\end{tabular}

Org—organotrophic bacteria; Act—Actinobacteria; Fun—fungi; Deh—dehydrogenases; Cat—catalase; Ure—urease; Pac—acid phosphatase; Pal—alkaline phosphatase; Glu— $\beta$-glucosidase; Aryl—arylsulfatase; $\mathrm{C}_{\mathrm{org}}$ —organic carbon content; $\mathrm{N}_{\text {total }}$-Total nitro gen content; $\mathrm{Co}_{\mathrm{av}}$ —available zinc content; $\mathrm{HAC}$-hydrolytic acidity; $\mathrm{EBC}$ - sum of exchangeable cations; $\mathrm{CEC}$ - cations exchange capacity; BS-base saturation; * coefficient of correlation significant at $p=0.05, n=9$. 
Table 19. Coefficients of correlation between variables in treatments sown with sandy clay loam.

\begin{tabular}{|c|c|c|c|c|c|c|c|c|c|c|c|c|c|c|c|c|c|c|c|}
\hline $\begin{array}{l}\text { Variable } \\
\text { Factors }\end{array}$ & Yield & $\mathrm{Co}_{\mathrm{av}}$ & Org & Act & Fun & Deh & Cat & Ure & Pac & Pal & Glu & Aryl & $\mathrm{pH}_{\mathrm{KCl}}$ & Corg & $\mathrm{N}_{\text {total }}$ & HAC & EBC & CEC & BS \\
\hline Dose & $-0.931 *$ & $0.830^{*}$ & $-0.989 *$ & $-0.999 *$ & $-0.968^{*}$ & $-0.987^{*}$ & $-0.999 *$ & $-0.962 *$ & $-0.996^{*}$ & $-0.999 *$ & $-0.997^{*}$ & $-0.999 *$ & $-0.945^{*}$ & $-0.984 *$ & $-0.990 *$ & $0.991 *$ & $-0.988^{*}$ & $-0.987 *$ & $-0.992^{\prime}$ \\
\hline Yield & & -0.976 * & $0.866^{*}$ & $0.922 *$ & $0.809^{*}$ & $0.978^{*}$ & $0.931^{*}$ & $0.797 *$ & $0.961^{*}$ & $0.919^{*}$ & $0.958^{*}$ & $0.920^{*}$ & $0.760^{*}$ & $0.850^{*}$ & $0.871^{*}$ & $-0.873 *$ & $0.863^{*}$ & $0.860^{*}$ & $0.877^{*}$ \\
\hline $\mathrm{Co}_{\mathrm{av}}$ & & & $-0.737^{*}$ & $-0.816^{*}$ & -0.663 & -0.910 * & -0.830 * & -0.647 & $-0.878^{*}$ & $-0.812 *$ & $-0.873 *$ & $-0.814^{*}$ & -0.602 & $-0.717^{*}$ & $-0.744^{*}$ & $0.747^{*}$ & $-0.734^{*}$ & $-0.729 *$ & -0.752 \\
\hline Org & & & & $0.992 *$ & $0.995^{*}$ & 0.951 * & $0.989 *$ & $0.992 *$ & $0.970^{*}$ & $0.993 *$ & $0.973 *$ & $0.992 *$ & $0.983^{*}$ & $0.999 *$ & $0.999 *$ & $-0.999 *$ & 0.999 * & $0.999 *$ & $0.999 *$ \\
\hline Act & & & & & $0.974^{*}$ & $0.982 *$ & 0.999 * & $0.969 *$ & 0.993 * & $0.999 *$ & 0.994 * & $0.999 *$ & 0.953 * & 0.988 * & 0.993 * & -0.994 * & $0.992 *$ & 0.991 * & $0.995 *$ \\
\hline Fun & & & & & & $0.914 *$ & $0.968^{*}$ & $0.999 *$ & $0.940^{*}$ & 0.975 * & $0.943 *$ & $0.974 *$ & $0.997 *$ & 0.997 * & $0.993 *$ & $-0.993 *$ & $0.995^{*}$ & 0.996 * & $0.992 *$ \\
\hline Deh & & & & & & & $0.987^{*}$ & 0.905 * & $0.998^{*}$ & 0.981 * & $0.997 *$ & $0.982 *$ & $0.879 *$ & 0.942 & 0.954 * & -0.956 * & 0.950 * & $0.948 *$ & 0.958 * \\
\hline Cat & & & & & & & & $0.962 *$ & $0.996^{*}$ & $0.999 *$ & $0.997 *$ & $0.999 *$ & $0.945^{*}$ & 0.984 * & 0.990 * & $-0.991 *$ & 0.988 * & $0.987^{*}$ & $0.992 *$ \\
\hline Ure & & & & & & & & & $0.933^{*}$ & 0.970 * & $0.936^{*}$ & $0.970 *$ & $0.998 *$ & 0.995 * & 0.991 * & $-0.990 *$ & $0.993 *$ & 0.994 * & $0.989 *$ \\
\hline Pac & & & & & & & & & & 0.992 * & $0.999 *$ & $0.993 *$ & 0.911 * & $0.963 *$ & 0.973 * & -0.974 * & $0.969^{*}$ & $0.968^{*}$ & 0.976 * \\
\hline $\mathrm{Pal}$ & & & & & & & & & & & $0.993 *$ & $0.999 *$ & $0.955^{*}$ & $0.989 *$ & $0.994 *$ & $-0.995 *$ & $0.992 *$ & $0.991 *$ & $0.995 *$ \\
\hline Glu & & & & & & & & & & & & $0.994 *$ & $0.915 *$ & $0.966 *$ & 0.975 * & $-0.976 *$ & $0.972 *$ & 0.970 * & $0.978 *$ \\
\hline Aryl & & & & & & & & & & & & & $0.954 *$ & 0.988 * & 0.994 * & $-0.994 *$ & $0.992 *$ & 0.991 * & $0.995^{*}$ \\
\hline $\mathrm{pH}_{\mathrm{KCl}}$ & & & & & & & & & & & & & & 0.988 * & 0.981 * & $-0.980 *$ & $0.984 *$ & $0.985 *$ & $0.979 *$ \\
\hline $\mathrm{C}_{\mathrm{org}}$ & & & & & & & & & & & & & & & $0.999 *$ & $-0.999 *$ & $0.999 *$ & $0.999 *$ & $0.999 *$ \\
\hline $\mathrm{N}_{\text {total }}$ & & & & & & & & & & & & & & & & $-0.999 *$ & $0.999 *$ & $0.999 *$ & $0.999 *$ \\
\hline HAC & & & & & & & & & & & & & & & & & $-0.999 *$ & $-0.999 *$ & $-0.999^{\prime}$ \\
\hline EBC & & & & & & & & & & & & & & & & & & $0.999 *$ & $0.999 *$ \\
\hline CEC & & & & & & & & & & & & & & & & & & & 0.999 \\
\hline
\end{tabular}

Explanations under Table 18. 


\section{Discussion}

The key role in biochemical processes in the soil and the impact on plant growth and development is played by microorganisms [27]. However, their activities can be disrupted by the introduction of various pollutants, such as heavy metals, into the soil environment. In the long term, this is associated with changes in their abundance and biodiversity, which disrupts the proper functioning of the soil [28]. Heavy metals can have different effects on microorganisms, but their action can be determined not only by the element introduced and its amount but also by the addition of different types of fertilizers or a group of microorganisms present in a given soil environment [29,30].

The analyzed groups of microorganisms reacted similarly in the experiment performed by Zaborowska et al. [29], in which cobalt (as other heavy metals) was introduced into the soil. It should be pointed out that this element does not cause such dramatic changes in the population of soil microorganisms compared to other heavy metals. Collins and Kinsela [31] noted that cobalt was essential for the growth and development of Rhizobium bacteria and, thus, for the formation of nodules on legume plants.

According to Pal et al. [32], fungi, especially genus Mortierella, are capable of accumulating large amounts of cobalt. The authors also mentioned other fungus genera, such as Aspergillus, Paecilomyces, Penicillium, Pythium, Rhizopus, and Trichoderma, which can be used to clean up the soil environment using cobalt biosorption. According to Prabhakaran et al. [33], this may be due to the fact that the studied microorganisms are capable of transformation and detoxification since they have the capability of extracellular sequestration, intracellular physical sequestration of metal by binding to protein or other ligands to avoid damage to the metal-sensitive cellular targets and the expulsion by active export of metal from cell. They allow microorganisms to grow in an environment contaminated with heavy metals. Unfortunately, heavy metals are sometimes toxic to less resistant microorganisms. This results in the development of evolutionary pressure, which, by causing the extinction of less adapted species, may contribute to a decrease in soil biodiversity. The mechanisms of resistance to heavy metals show a certain similarity to antibiotic resistance. They can, in a sense, be regarded as a kind of virulence factor that may act synergistically, which may pose a potential hazard to the health and lives of humans, plants, and animals coming into contact with a soil containing such microorganisms [34]. The microorganisms which exhibit such a high degree of resistance to heavy metal contamination may potentially be used in the bioremediation of environments contaminated with heavy metals [35].

For the assessment of the quality and fertility of soil contaminated with heavy metals, the enzymatic activity will be considered as one of the basic parameters [33-35]. Elements may modify the microbiological activity of the soil, thus indirectly affecting soil enzymes or directly inhibiting their activity [36-39]. Boros-Lajszner et al. [17] found that the zeolite under the study also slightly mitigated the negative effects of nickel on soil biochemical activity. Tomczak and Kaminski [40] reported that this might be caused by selectivity in absorbing heavy metals from the environment. The method of use contributed to the better effect of zeolite, as higher enzyme activity was observed in the soil sown with maize.

The action of sorbents, particularly the molecular sieve, might be due to their high ion exchange and sorption capacity [2]. The molecular sieve effect, which is related to the specific selectivity of the shape, is also not without importance [41].

The tested metal, like iron, is moved to plant tissues by active and passive transport. This results in antagonism in cation uptake, especially between cobalt and other elements, i.e., iron and manganese [42]. Differences in uptake and transport of cobalt between monocotyledon (wheat) and dicotyledon (tomato) plants were also noted by Bakkaus et al. [43]. Cobalt and iron were transported in the same manner in wheat. As the authors suggested, these elements were transported differently in tomato because of the formation of protective mechanisms.

Biosorption of cobalt by plants is a species-specific feature. The transfer of this element through the food chain is not a significant threat, as most plants are not able to accumulate cobalt [42]. This is 
due not only to the movement of this element in the soil-water-plant system but most often to the low content of this metal in soil.

The soils used in the experiment have good physical and chemical properties, particularly $\mathrm{pH}$ and granulometric composition. The sorbents used in the experiment had no significant effect on the physicochemical properties of the soil. This was confirmed by a study conducted by Kosiorek and Wyszkowski [44], who used alleviating substances, including zeolite. The contamination of soil with zeolite had a greater effect. Similar results were obtained by Kosiorek and Wyszkowski [44], who observed that increasing contamination with cobalt decreased the soil $\mathrm{pH}$, decreased the content of the total alkaline exchangeable cations, and increased the hydrolytic acidity. This is reflected in the active biological life of the soil and, consequently, in the amount of cobalt absorbed by the plants. In effect, they can "defend themselves" against the negative effect of heavy metals, including cobalt $[45,46]$.

\section{Conclusions}

In conclusion, although cobalt is an essential microelement for soil microorganisms, excessive amounts can be toxic to them. It can also inhibit soil biochemistry and plant development. The indices of the effects of heavy metal and sorbents on the biological properties of soil in this study, as well as the cobalt content and uptake by maize, provided the data on the effect of cobalt on soil quality. These results suggested that not every sorbent could be used to neutralize cobalt. The study found that a molecular sieve had a better effect than the Bio.Zeo.S.01 zeolite. The granulometric composition of both the soils had no effect on the amount of cobalt phytoavailability. The biological life and the crop yield were better in the sandy clay loam than in the loamy sand. This might be associated with a higher content of organic and mineral colloids, on which sorption of cobalt takes place. Also, not without significance is the fact that more compact soil contains more organic carbon and nitrogen

Author Contributions: E.B.-L., J.W., and J.K. framed the methodology, conceived the ideas, and designed the paper. E.B.-L. wrote the paper, prepared the tables and figures, and collected the data. J.W. corresponding author. J.W. and J.K. reviewed the manuscript. All authors contributed significantly to the discussion of the results and the preparation of the manuscript. All authors have read and agreed to the published version of the manuscript.

Funding: This study was supported by the Ministry of Science and Higher Education funds for statutory activity. Project financially supported by Minister of Science and Higher Education in the range of the program entitled "Regional Initiative of Excellence" for the years 2019-2022, Project No. 010/RID/2018/19, amount of funding 12.000.000 PLN.

Conflicts of Interest: The authors declare no conflict of interest.

\section{References}

1. McBain, J. The Sorption of Gases and Vapours by Solids; Routledge \& Sons: London, UK, 1932.

2. Galamboš, M.; Suchánek, P.; Rosskopfová, O. Sorption of anthropogenic adionuclides on natural and synthetic inorganic sorbents. J. Radioanal. Nucl. Chem. 2012, 293, 613-633. [CrossRef]

3. Lin, D.; Zhou, Q. Effects of Soil Amendments on the extractability and speciation of cadmium, lead, and copper in a contaminated soil. Bull. Environ. Contam. Toxicol. 2009, 83, 136-140. [CrossRef] [PubMed]

4. Albanese, S.; Sadeghi, M.; Lima, A.; Cicchella, D.; Dinelli, E.; Valera, P.; Falconi, M.; Demetriades, A.; Vivo, B. GEMAS: Cobalt, $\mathrm{Cr}, \mathrm{Cu}$ and $\mathrm{Ni}$ distribution in agricultural and grazing land soil of Europe. J. Geochem. Explor. 2015, 154, 81-93. [CrossRef]

5. Biswasa, B.; Sarkara, B.; Mandala, A.; Naidua, R. Heavy metal-immobilizing organoclay facilitates polycyclic aromatichydrocarbon biodegradation in mixed-contaminated soil. J. Hazard. Mater. 2015, 298, 129-137. [CrossRef]

6. Turner, R.J. Metal-based antimicrobial strategies. Microb. Biotechnol. 2017, 10, 1062-1065. [CrossRef]

7. Di Gregorio, S.; Gentini, A.; Siracusa, G.; Becarelli, S.; Azaizeh, H.; Lorenzi, R. Phytomediated biostimulation of the autochthonous bacterial community for the acceleration of the depletion of polycyclic aromatic hydrocarbons in contaminated sediments. BioMed Res. Int. 2014, 2014, 891630. [CrossRef] 
8. Di Gregorio, S.; Giorgetti, L.; Ruffini Castiglione, M.; Mariotti, L.; Lorenzi, R. Phytoremediation for improving the quality of effluents from a conventional tannery wastewater treatment plant. Int. J. Environ. Sci. Technol. 2014, 12, 1387-1400. [CrossRef]

9. Di Gregorio, S.; Siracusa, G.; Becarelli, S.; Mariotti, L.; Gentini, A.; Lorenzi, R. Isolation and characterization of a hydrocarbonoclastic bacterial enrichment from total petroleum hydrocarbon contaminated sediments: Potential candidates for bioaugmentation in bio-based processes. Environ. Sci. Pollut. Res. 2016, 23, 10587-10594. [CrossRef]

10. Siracusa, G.; Becarelli, S.; Lorenzi, R.; Gentini, A.; Di Gregorio, S. PCB in the environment: Bio-based processes for soil decontamination and management of waste from the industrial production of Pleurotusostreatus. New Biotechnol. 2017, 39, 232-239. [CrossRef]

11. Wang, J.; Chen, X.; Chi, Y.; Chu, S.; Hayat, K.; Zhi, Y.; Hayat, S.; Terziev, D.; Zhang, D.; Zhou, P. Optimization of NPK fertilization combined with phytoremediation of cadmium contaminated soil by orthogonal experimentl. Ecotoxicol. Environ. Saf. 2020, 189, 109997. [CrossRef]

12. Zeng, X.; Zou, D.; Wang, A.; Zhou, Y.; Liu, Y.; Li, Z.; Liu, L.; Wang, H.; Zeng, Q.; Xiao, Z. Remediation of cadmium-contaminated soils using Brassica napus: Effect of nitrogen fertilizers. J. Environ. Manag. 2020, 255, 109885. [CrossRef] [PubMed]

13. Andrade, L.F.; Davide, L.C.; Gedraite, L.S. The effect of cyanide compounds, fluorides, aluminum, and inorganic oxides present in spent pot liner on germination and root tip cells of Lactuca sativa. Ecotoxicol. Environ. Saf. 2010, 73, 626-631. [CrossRef] [PubMed]

14. Sun, Y.; Zhao, D.; Xu, Y.; Wang, L.; Liang, X.; Shen, Y. Effects of sepiolite on stabilization remediation of heavy metal-contaminated soil and its ecological evaluation. Front. Environ. Sci. Eng. 2016, 10, 85-92. [CrossRef]

15. Google Maps. Available online: https://www.google.com/maps/place/Olsztyn/Tomaszkowo (accessed on 1 September 2019).

16. Dziennik Ustaw Rzeczypospolitej Polskiej. Available online: http://prawo.sejm.gov.pl/isap.nsf/download. xsp/WDU20160001395/O/D20161395.pdf (accessed on 11 December 2019). (In Polish)

17. Boros-Lajszner, E.; Wyszkowska, J.; Kucharski, J. Use of zeolite to neutralise nickel in a soil environment. Environ. Monit. Assess. 2018, 190, 54. [CrossRef] [PubMed]

18. Kosiorek, M.; Wyszkowski, M. Effect of manure, clay, charcoal, zeolite, and calcium oxide on some properties of soil contaminated with cobalt. Soil Sci. Ann. 2017, 68, 149-154. [CrossRef]

19. Alexander, M. Microorganisms and chemical pollution. Bioscience 1973, 23, 335-344. [CrossRef]

20. Parkinson, D.; Gray, F.R.G.; Williams, S.T. Methods of Studying Ecology of Soil Microorganism; Blackweel Scientific Publication: Oxford/Endinburgh, UK, 1971.

21. Martin, J. Use of acid rose bengal and streptomycin in the plate method for estimating soil fungi. Soil Sci. 1950, 69, 215-233. [CrossRef]

22. Öhlinger, R. Dehydrogenase Activity with the Substrate TTC. In Methods in Soil Biology; Schinner, F., Öhlinger, R., Kandeler, E., Margesin, R., Eds.; Springer: Berlin/Heidelberg, Germany, 1996; pp. 241-243.

23. Alef, K.; Nannipieri, P. Urease Activity. In Methods in Applied Soil Microbiology and Biochemistry; Alef, K., Nannipieri, P., Eds.; Academic PressHarcourt Brace \& Company: London, UK, 1998; pp. 316-365.

24. Kaczyńska, G.; Borowik, A.; Wyszkowska, J. Soil dehydrogenases as an indicator of contamination of the environment with petroleum products. Water Air Soil Pollut. 2015, 226, 372. [CrossRef]

25. PN-ISO 11047. Soil Quality-Determination of Cadmium, Chromium, Cobalt, Copper, Lead, Manganese, Nickel and Zinc in Aqua Regia Extracts of Soil-Flame and Electrothermal Atomic Absorption Spectrometric Methods; International Organization for Standardization: Geneva, Switzerland, 2016; Available online: https://pzn. pkn.pl/kt/info/published/9000128800 (accessed on 1 September 2019).

26. Dell Inc. Dell Statistica (Data Analysis Software System); Version 13.1; Dell Inc.: Tulsa, OK, USA, 2016.

27. Li, M.; Cheng, X.; Guo, H. Heavy metal removal by biomineralization of urease producing bacteria isolated from soil. Int. Biodeter. Biodegr. 2013, 76, 81-85. [CrossRef]

28. Baldrian, P.; Trögl, J.; Frouz, J.; Šnajdr, J.; Valášková, V.; Merhautová, V.; Cajthaml, T.; Herinková, J. Enzyme activities and microbial biomass in topsoil layer during spontaneous succession in spoil heaps after brown coal mining. Soil Biol. Biochem. 2008, 40, 2107-2115. [CrossRef]

29. Zaborowska, M.; Kucharski, J.; Wyszkowska, J. Biological activity of soil contaminated with cobalt, tin and molybdenum. Environ. Monit. Assess. 2016, 188, 398. [CrossRef] 
30. Strachel, R.; Wyszkowska, J.; Baćmaga, M. The Role of compost in stabilizing the microbiological and biochemical properties of zinc-stressed soil. Water Air Soil Pollut. 2017, 228, 349. [CrossRef]

31. Collins, R.N.; Kinsela, A.S. Pedogenic factors and measurements of the plant uptake of cobalt. Plant Soil 2011, 339, 499-512. [CrossRef]

32. Pal, A.; Ghosh, S.; Paul, A.K. Biosorption of cobalt by fungi from serpentine Soil of Andaman. Bioresour. Technol. 2006, 97, 1253-1258. [CrossRef] [PubMed]

33. Prabhakaran, P.; Aqeel Ashraf, M.; Wan Mohd Noor, W. Microbial stress response to heavy metal in the environment. RSC Adv. 2016, 6, 109862-109877. [CrossRef]

34. Pitondo-Silva, A.; Gonçalves, G.B.; Stehling, E.G. Heavy metal resistance and virulence profile in Pseudomonas aeruginosa isolated from Brazilian soils. APMIS 2016, 124, 681-688. [CrossRef] [PubMed]

35. Ahemad, M. Implications of bacterial resistance against heavy metals in bioremediation: A review. IIOABJ 2012, 3, 39-46.

36. Thavamani, P.; Malik, S.; Beer, M.; Megharaj, M.; Naidu, R. Microbial activity and diversity in long-term mixed contaminated soils with respect to polyaromatic hydrocarbons and heavy metals. J. Environ. Manag. 2012, 99, 10-17. [CrossRef] [PubMed]

37. Jośko, I.; Oleszczuk, P.; Futa, B. The effect of inorganic nanoparticles $\left(\mathrm{ZnO}, \mathrm{Cr}_{2} \mathrm{O}_{3}, \mathrm{CuO}\right.$ and $\left.\mathrm{Ni}\right)$ and their bulk counterparts on enzyme activities in different soils. Geoderma 2014, 232-234, 528-537. [CrossRef]

38. Igbinosa, E.O. Effect of cassava mill effluent on biological activity of soil microbial community. Environ. Monit. Assess. 2015, 187, 418. [CrossRef] [PubMed]

39. Pan, J.; $\mathrm{Yu}, \mathrm{L}$. Effects of $\mathrm{Cd}$ or/and $\mathrm{Pb}$ on soil enzyme activities and microbial community structure. Ecol. Eng. 2011, 37, 1889-1894. [CrossRef]

40. Tomczak, E.T.; Kamiński, W.L. Application of genetic algorithms to determine heavy metal ions sorption dynamics on clinoptilolite bed. Chem. Process. Eng. 2012, 33, 103-116. [CrossRef]

41. Abdolmohammad-Zadeh, H.; Ebrahimzadeh, E. Determination of cobalt in water samples by atomic absorption spectrometry after pre-concentration with a simple ionic liquid-based dispersive liquid-liquid micro-extraction methodology. Cent. Eur. J. Chem. 2010, 8, 617-625. [CrossRef]

42. Shi, Y.; Huang, Z.; Liu, X.; Imran, S.; Peng, L.; Dai, R.; Deng, Y. Environmental materials for remediation of soils contaminated with lead and cadmium using maize (Zea mays L.) growth as a bioindicator. Environ. Sci. Pollut. Res. 2016, 23, 6168-6178. [CrossRef]

43. Bakkaus, E.; Gouget, B.; Gallien, J.P.; Khodja, H.; Carrot, F.; Morel, J.L.; Collins, R. Concentration and distribution of cobalt in higher plants: The use of micro-PIXE spectroscopy. Nucl. Instrum. Methods B 2005, 231, 350-356. [CrossRef]

44. Kosiorek, M.; Wyszkowski, M. Content of organic carbon, total nitrogen and available forms of macronutrients in soil contaminated with cobalt. J. Elem. 2017, 22, 1427-1437. [CrossRef]

45. Wendling, L.A.; Kirbz, J.K.; Kosiorek, M.; Wyszkowski, M.; Mclaughlin, M.J. Aging effects on cobalt availability in soils. Environ. Toxicol. Chem. 2009, 28, 1609-1617. [CrossRef]

46. Edwards, A.C.; Cuull, M.; Sinclair, A.H.; Walker, R.L.; Watson, C.A. Elemental status (Cu, Mo, Co, B, S, Zn) of Scottish agricultural soils compared with a soil-based risk assessment. Soil Use Manag. 2012, 28, 167-176. [CrossRef]

(C) 2020 by the authors. Licensee MDPI, Basel, Switzerland. This article is an open access article distributed under the terms and conditions of the Creative Commons Attribution (CC BY) license (http://creativecommons.org/licenses/by/4.0/). 